\title{
Influence of water vapour on the height distribution of positive ions, effective recombination coefficient and ionisation balance in the quiet lower ionosphere
}

\author{
V. Barabash ${ }^{1}$, A. Osepian ${ }^{2}$, and P. Dalin ${ }^{3}$ \\ ${ }^{1}$ Luleå University of Technology, Rymdcampus 1, 98192 Kiruna, Sweden \\ ${ }^{2}$ Polar Geophysical Institute, Halturina 15, 183023 Murmansk, Russia \\ ${ }^{3}$ Swedish Institute of Space Physics, Rymdcampus 1, 98192 Kiruna, Sweden \\ Correspondence to: V. Barabash (victoria.barabash@ltu.se)
}

Received: 12 June 2013 - Revised: 22 January 2014 - Accepted: 28 January 2014 - Published: 11 March 2014

\begin{abstract}
Mesospheric water vapour concentration effects on the ion composition and electron density in the lower ionosphere under quiet geophysical conditions were examined. Water vapour is an important compound in the mesosphere and the lower thermosphere that affects ion composition due to hydrogen radical production and consequently modifies the electron number density. Recent lowerionosphere investigations have primarily concentrated on the geomagnetic disturbance periods. Meanwhile, studies on the electron density under quiet conditions are quite rare. The goal of this study is to contribute to a better understanding of the ionospheric parameter responses to water vapour variability in the quiet lower ionosphere. By applying a numerical $\mathrm{D}$ region ion chemistry model, we evaluated efficiencies for the channels forming hydrated cluster ions from the $\mathrm{NO}^{+}$ and $\mathrm{O}_{2}^{+}$primary ions (i.e. $\mathrm{NO}^{+} \cdot \mathrm{H}_{2} \mathrm{O}$ and $\mathrm{O}_{2}^{+} \cdot \mathrm{H}_{2} \mathrm{O}$, respectively), and the channel forming $\mathrm{H}^{+}\left(\mathrm{H}_{2} \mathrm{O}\right)_{n}$ proton hydrates from water clusters at different altitudes using profiles with low and high water vapour concentrations. Profiles for positive ions, effective recombination coefficients and electrons were modelled for three particular cases using electron density measurements obtained during rocket campaigns. It was found that the water vapour concentration variations in the mesosphere affect the position of both the $\mathrm{Cl}_{2}^{+}$proton hydrate layer upper border, comprising the $\mathrm{NO}^{+}\left(\mathrm{H}_{2} \mathrm{O}\right)_{n}$ and $\mathrm{O}_{2}^{+}\left(\mathrm{H}_{2} \mathrm{O}\right)_{n}$ hydrated cluster ions, and the $\mathrm{Cl}_{1}^{+}$hydrate cluster layer lower border, comprising the $\mathrm{H}^{+}\left(\mathrm{H}_{2} \mathrm{O}\right)_{n}$ pure proton hydrates, as well as the numerical cluster densities. The water variations caused large changes in the effective recombination coefficient and electron density between altitudes of
\end{abstract}

75 and $87 \mathrm{~km}$. However, the effective recombination coefficient, $\alpha_{\text {eff }}$, and electron number density did not respond even to large water vapour concentration variations occurring at other altitudes in the mesosphere. We determined the water vapour concentration upper limit at altitudes between 75 and $87 \mathrm{~km}$, beyond which the water vapour concentration ceases to influence the numerical densities of $\mathrm{Cl}_{2}^{+}$and $\mathrm{Cl}_{1}^{+}$, the effective recombination coefficient and the electron number density in the summer ionosphere. This water vapour concentration limit corresponds to values found in the $\mathrm{H}_{2} \mathrm{O}-1$ profile that was observed in the summer mesosphere by the Upper Atmosphere Research Satellite (UARS). The electron density modelled using the $\mathrm{H}_{2} \mathrm{O}-1$ profile agreed well with the electron density measured in the summer ionosphere when the measured profiles did not have sharp gradients. For sharp gradients in electron and positive ion number densities, a water profile that can reproduce the characteristic behaviour of the ionospheric parameters should have an inhomogeneous height distribution of water vapour.

Keywords. Ionosphere (ion chemistry and composition)

\section{Introduction}

Solar radiation is the main source of ion production in the daytime ionosphere under quiet geophysical conditions. Ion production below $100 \mathrm{~km}$ during daytime is created by several wavelength ranges, namely, hard X-rays (less than $1 \mathrm{~nm}$ ), soft X-rays (1-10 nm), $L y-\beta(102.6 \mathrm{~nm})$ and $L y-\alpha(121.6 \mathrm{~nm})$ emissions, the continuum radiation at $102.6-111.8 \mathrm{~nm}$ and 
galactic cosmic rays. Ionisation in the nighttime ionosphere is produced by scattered radiation at $304 \mathrm{~nm}, 584 \mathrm{~nm}, L y$ $\alpha$ and $L y-\beta$ lines (Brasseur and Salomon, 1986). Ions and electrons in the D region are mixed with the dense neutral atmosphere and undergo collisions with neutral particles, therefore changing the physical and chemical states of the medium. The primary ions, i.e. $\mathrm{NO}^{+}, \mathrm{O}_{2}^{+}, \mathrm{O}_{2}^{-}$and $\mathrm{O}^{-}$ (Brasseur and Salomon, 1986), initiate complex chains of ion-molecule reactions with chemically active minor neutral species (e.g. $\mathrm{O}, \mathrm{O}_{3}, \mathrm{NO}, \mathrm{NO}_{2}, \mathrm{H}_{2} \mathrm{O}, \mathrm{HO}_{\mathrm{x}}, \mathrm{O}_{2}\left(1 \Delta_{\mathrm{g}}\right), \mathrm{CO}_{2}$, $\mathrm{N}_{2} \mathrm{O}_{5}, \mathrm{HNO}_{3}$ and $\mathrm{HCl}$ ) (Solomon et al., 1981; Verronen et al., 2008, 2011; Verronen and Lehmann, 2013; Winkler et al., 2009) resulting in the formation and presence of various ion clusters and simple and complex negative ions in the D region, with number densities depending on altitude, season, local time and other factors.

Water vapour is an important compound in the upper atmosphere that influences ion composition due to hydrogen radical production and consequently modifies the ion composition and electron number density. Recent research has been quite successful in mapping the water vapour pattern in the lower mesosphere and explaining possible mechanisms for cluster ion formation (Solomon et al., 1981; Gumbel and Witt, 2002; Sonnemann et al., 2005, 2012; Hervig and Siskind, 2006; Lossow et al., 2007; Grygalashvyly et al., 2009; Hartogh et al., 2010; Gabriel et al., 2011). However, the ionospheric parameter responses to water vapour variability in the mesosphere and the lower thermosphere are very complicated.

Current experimental knowledge about the electron density and ion composition in the quiet lower ionosphere, i.e. when the $\mathrm{D}$ region is weakly ionised, is primarily based on in situ measurements obtained during periodical rocket campaigns. However, rocket ion and electron measurements do not provide a complete representation of ionospheric structure due to their spatial and temporal limitations. New possibilities have recently become available, e.g. the Doppler radar operating at $3.17 \mathrm{MHz}$ at the Andoya Rocket Range in Norway $\left(69.3^{\circ} \mathrm{N}, 16.0^{\circ} \mathrm{E}\right)$ (Singer et al., 2011). The situation can be further improved by applying theoretical models in combination with available experimental data. Depending on specific goals of a study, complex or simplified ion chemistry schemes may be applied.

\subsection{Detailed ion chemistry schemes}

Laboratory (Ferguson, 1971a, b, 1974; Fehsenfeld and Fergusson, 1974; Smith et al., 1976, 1979; Smith and Church, 1977; Albritton, 1978; Cosby et al., 1978) and theoretical studies (Shimazaki, 1984) of ion-molecule reactions created opportunities for the development of $\mathrm{D}$ region ionchemical models that include different ionisation sources. The main task and challenge for ion-chemical model formulation is the correct description of cluster ion formation from primary positive ions and complex negative ion formation and loss in various geophysical situations, e.g. during quiet or disturbed conditions, different seasons, and solar illumination. Such models are able to explain cluster and complex negative ion of characteristics and provide information on the altitude distribution of ionosphere parameters. This information cannot be directly retrieved from standard measurements. However, the information is very important for understanding the physics and chemistry of the specific medium and for solving practical problems.

Fehsenfeld and Fergusson (1969) were the first to show that $\mathrm{NO}^{+}$ions can be successively hydrated in the mesosphere. Because of the relatively low water vapour concentration and low pressure in the mesosphere, direct three-body association of water vapour is too slow compared to the rapid loss rate imposed on cluster ions by dissociative recombination. Association processes with abundant gases, i.e. $\mathrm{N}_{2}$ and $\mathrm{CO}_{2}$, have been studied by Dunkin et al. (1971) and Ferguson $(1974,1976)$. Thomas $(1976 a$, b) introduced cluster formation reactions between $\mathrm{NO}^{+}, \mathrm{CO}_{2}$ and $\mathrm{N}_{2}$ into a positive ion chemistry model for the daytime $\mathrm{D}$ region and investigated the role of these reactions in $\mathrm{NO}^{+}$hydration and their dependence on mesospheric temperatures. Cluster ion formation from $\mathrm{O}_{2}^{+}$was proposed by Fehsenfeld and Fergusson (1969) and is based on the mutual three-body formation of $\mathrm{O}_{4}^{+}$and $\mathrm{O}_{2}^{+}\left(\mathrm{H}_{2} \mathrm{O}\right)$ and subsequent reactions with water vapour and three-body attachments of water molecules to form higher-order proto-hydrated cluster ions, i.e. $\mathrm{H}^{+}$ $\left(\mathrm{H}_{2} \mathrm{O}\right)_{n}$.

An ion model of the mesosphere with complex negative ion chemistry was presented by Wisemberg and Kockarts (1980). They evaluated quantitatively the role of various paths in the ion-chemical model. According to Smirnova and Vlaskov (1982a, b) and Fritzenwallner and Kopp (1998), hydrated ions, i.e. $\mathrm{CO}_{3}^{-}\left(\mathrm{H}_{2} \mathrm{O}\right)_{n}$ and $\mathrm{NO}_{3}^{-}\left(\mathrm{H}_{2} \mathrm{O}\right)_{n}$, detected during a few negative ion composition measurement periods (a mass greater than $70 \mathrm{amu}$ corresponds to negative cluster ions) may be abundant in certain conditions, e.g. the summer twilight during noctilucent cloud events. However, the effect of negative cluster ions on negative ion and electron number densities and the altitude distribution of primary negative ions is not well pronounced. Turco and Sechrist (1972a, b), Thomas and Bowman (1986), Hodges et al. (1980) and Reid (1987) have shown that photodissociation of molecular ions and photodetachment of electrons are important for ion chemistry and electron height distributions in the lower ionosphere.

Ion-molecule reactions participating in the chemical transformations of primary ions in the D region and many final ions are included in the detailed schemes by Arnold and Krankowsky (1971), Arnold (1980), Fehsenfeld and Fergusson (1969), Dunkin et al. (1971), Ferguson (1974, 1976), Thomas (1976a, b), Reid (1977), Chakrabarty et al. (1978), Wisemberg and Kockarts (1980), Solomon et al. (1982), Thomas and Bowman (1986), and Turunen et 
al. (1992). The impact of ion chemistry on the neutral species $\left(\mathrm{NO}_{\mathrm{x}}, \mathrm{HO}_{\mathrm{x}}\right)$ has been studied in most cases during the solar proton events (Jackman and Meade, 1988; Jackman et al., 1995, 2001, 2005; Rohen et al., 2005). Lopez-Puertas et al. (2005) investigated changes of neutral species during a solar proton event, but did not use any model results to explain his observations. Steady-state, time-dependent and global two-dimensional ion-chemistry models have been presented by Kull et al. (1997), Verronen et al. (2002, 2008, 2011), Kazil et al. (2003), and Winkler et al. (2009). These complex models allow the investigation of the coupling mechanisms between neutral particle chemistry and ion chemistry. A validation of the models has been performed in most cases during strong ionospheric disturbances (Verronen et al., 2008, 2011; Winkler et al., 2009). Particularly, these models made it possible to explain ozone depletion and nitric oxide enhancement observed during solar proton events (Solomon et al., 1981, 1982; Zadorozhny, 1982; Seppala et al., 2004, 2007; Verronen et al., 2002, 2005, 2006; Funke et al., 2011). Moreover, it is possible to apply these complex models to examine ion concentrations, including both the final and intermediate cluster ions, if the complete experimental ion composition data required for model-observation comparisons are available. However, as previous studies have suggested, these complex models have some intrinsic limitations that may be associated with inadequacies in the reaction rate constants and uncertainties in some chemical reaction paths included in the detailed ion and neutral chemical schemes. Some ionmolecule reactions are still under discussion. There are also limitations on mass spectrometer observations.

\subsection{Simplified ion chemistry schemes}

Another approach for modelling the lower ionosphere is based on a reasonable simplification of the ion-molecule processes scheme (Haug and Landmark, 1970; Mitra and Rowe, 1972; Danilov and Yaichnikov, 1985; Smirnova, 1982, 1983a, b; Smirnova et al., 1988). The simplified chemical schemes are likely to avoid possible uncertainties in describing cluster, intermediate positive and negative ion concentrations by selecting the ion-molecule reactions that are the most important for chemical transformations. Less important chemical processes, i.e. with large reaction rate constant uncertainties, are not considered. These schemes implement ion bond energies, rate constants and efficiencies for each reaction participating in the chemical transformation processes. Moreover, the dependence of these parameters on temperature and intermediate ion thermal decomposition are also represented.

Furthermore, models with simplified ion chemistry schemes must accurately reproduce height distributions of electrons and main final ions. These models must also provide a correct description of the generalised principal characteristics of the ionosphere, namely,
- $f^{+}=\left[\right.$Cluster $\left.^{+}\right] /\left(\left[\mathrm{NO}^{+}\right]+\left[\mathrm{O}_{2}^{+}\right]\right)$, a ratio of positive cluster ions to primary molecular ions,

$-\lambda=N^{-} / N_{\mathrm{e}}$, a ratio of negative ion number density to electron number density,

- $h_{f+=1}$ and $h_{\lambda=1}$, the transition heights, and the effective recombination coefficients

for various solar zenith angles (solar illumination), seasons and geomagnetic disturbance levels.

The ion-molecule reaction efficiencies together with ionisation and recombination depend on local concentrations of chemically active minor neutral constituents and affect the ionosphere structure. The altitude and spatial distributions of these minor neutral constituents depend on the solar zenith angle, season, latitude, solar activity, ionisation sources, transport, diffusion and other factors. Therefore, the modelled ionospheric parameters, which are based on both complex detailed and simple ion chemistry schemes (Smirnova, 1982, 1983a, b), depend on the choice of minor neutral constituent profiles introduced into the model for each particular case study. Osepian et al. (2008, 2009b) implemented a simplified ion chemistry scheme to investigate the role of atomic oxygen and ozone concentrations in the ionisation balance in the $\mathrm{D}$ region during solar proton events. Moreover, the $\mathrm{NO}, \mathrm{O}$ and $\mathrm{O}_{3}$ concentration effects on the electron number density in the quiet $\mathrm{D}$ region between 60 and $100 \mathrm{~km}$ were studied by Barabash et al. (2012).

In the current study, the simplified ion chemistry model developed by Smirnova and Vlaskov (1982a, 1983) has been applied to examine the water vapour concentration effects on a few ionospheric parameters, namely,

- the efficiency of the channels forming non-proton $\left(\mathrm{Cl}_{1}^{+}\right)$and proton $\left(\mathrm{Cl}_{2}^{+}\right)$hydrate layers in the $\mathrm{D}$ region and

- the variability of positive ions, electron number densities and effective recombination coefficients.

Additionally, $\mathrm{H}_{2} \mathrm{O}$ profiles that are more consistent with measured electron densities between 60 and $100 \mathrm{~km}$ in summer and winter during quiet geophysical conditions have been defined.

\section{Theoretical model of the lower ionosphere}

The simplified ion chemistry model (Smirnova, 1982, 1983a, b; Smirnova et al. 1988) computes numerical densities for four positive ions (i.e. $\mathrm{NO}^{+}, \mathrm{O}_{2}^{+}, \mathrm{Cl}_{1}^{+}, \mathrm{Cl}_{2}^{+}$), four negative ions (i.e. $\mathrm{O}_{2}^{-}, \mathrm{O}^{-}, \mathrm{CO}_{3}^{-}, \mathrm{NO}_{3}^{-}$) and electrons. Smirnova and Vlaskov (1982a, b, 1983) and Smirnova et al. (1988) describe the complete chemical scheme formulation and verification. The scheme has been implemented as a main module in the theoretical D region model developed at the Polar Geophysical Institute (PGI model). 
Nitric oxide (NO) ionised by $\mathrm{Ly}-\alpha$ is the main source of electrons and positive ions between 65 and $85 \mathrm{~km}$ in the quiet ionosphere. The bond energy for $\mathrm{NO}^{+}\left(\mathrm{H}_{2} \mathrm{O}\right)_{n}$ ions is high compared to one of the intermediate ions, and the rate of their thermal decomposition is low. The estimations of the rate processes on the second and third hydration stages have shown that the main process intermediate $\mathrm{NO}^{+}\left(\mathrm{H}_{2} \mathrm{O}\right)_{1,2} . X$ (where $X$ is $\mathrm{N}_{2}$ or $\mathrm{CO}_{2}$ ) ion loss is due to thermal decomposition. Reid (1977) showed that the formation rate of cluster ions from the $\mathrm{NO}^{+}$ion is strongly temperature-dependent, which is primarily due to the temperature dependence of the $\mathrm{NO}^{+}\left(\mathrm{H}_{2} \mathrm{O}\right)$ formation rate via the two-stage hydration mechanism. The efficiency of the $\mathrm{NO}^{+}$hydration channel, $B\left(\mathrm{NO}^{+}\right)$, including both direct and indirect hydration, is expressed via ion transformation process rate constants and $\mathrm{H}_{2} \mathrm{O}, \mathrm{N}_{2}$ and $\mathrm{CO}_{2}$ concentrations:

$$
\begin{gathered}
B\left(\mathrm{NO}^{+}\right)=\left[\mathrm{H}_{2} \mathrm{O}\right]\left(r_{1}\left[\mathrm{~N}_{2}\right]+\frac{r_{2}\left[\mathrm{~N}_{2}\right]^{2} r_{4}}{\mathrm{C}}+\frac{r_{6}}{r_{6}\left[\mathrm{H}_{2} \mathrm{O}\right]+r_{-5}\left[\mathrm{~N}_{2}\right]}\right. \\
\left.\left(r_{5}\left[\mathrm{CO}_{2}\right]\left[\mathrm{N}_{2}\right]+\frac{r_{2}\left[\mathrm{~N}_{2}\right]^{2} r_{3}\left[\mathrm{CO}_{2}\right]}{\mathrm{C}}\right)\right),
\end{gathered}
$$

where $\mathrm{C}=r_{-2}\left[\mathrm{~N}_{2}\right]+r_{3}\left[\mathrm{CO}_{2}\right]+r_{4}\left[\mathrm{H}_{2} \mathrm{O}\right]$ and $r_{1}, r_{2}, r_{-2}, r_{5}$, and $r_{-5}$ are functions of temperature. The direct hydration efficiency of $\mathrm{NO}^{+}$is $v=r_{1} \cdot\left[\mathrm{H}_{2} \mathrm{O}\right] \cdot\left[\mathrm{N}_{2}\right]$. The efficiency $B\left(\mathrm{NO}^{+}\right)$is inversely proportional to the temperature (Smirnova and Vlaskov, 1982b; Smirnova, 1982, 1983a, b).

Furthermore $\mathrm{O}_{2}^{+}$ions are lost via charge exchange and reactions, including the formation of intermediate $\mathrm{O}_{4}^{+}$and $\mathrm{O}_{2}^{+} \cdot \mathrm{N}_{2}$ ions followed by the $\mathrm{O}_{2}^{+} \cdot \mathrm{H}_{2} \mathrm{O}$ cluster ion formation. The $\mathrm{O}_{2}^{+}$hydration channel becomes the primary cluster ion source during strong ionospheric disturbances that are caused by precipitating particles when the $\mathrm{O}_{2}^{+}$concentration is largely increased compared to the $\mathrm{NO}^{+}$concentration. The efficiency of the $\mathrm{O}_{2}^{+}$hydration channel, $B\left(\mathrm{O}_{2}^{+}\right)$, was derived according to Fehsenfeld and Fergusson (1969), Ferguson (1976) and Chakrabarty (1978) and includes, in addition to the typically considered processes, an additional $\mathrm{O}_{2}^{+}\left(\mathrm{H}_{2} \mathrm{O}\right)$ formation path via the $\mathrm{O}_{2}^{+} \cdot \mathrm{N}_{2}$ cluster ion and thermal $\mathrm{O}_{4}^{+}$decomposition:

$$
B\left(\mathrm{O}_{2}^{+}\right)=\frac{K_{1}\left[O_{2}\right]^{2}+v_{1}\left[N_{2}\right]^{2}}{\frac{K_{2}[\mathrm{O}]+K_{3}\left[\mathrm{O}_{2}\left(1 \Delta_{\mathrm{g}}\right)\right]+K_{-1}\left[\mathrm{O}_{2}\right]}{K_{4}\left[\mathrm{H}_{2} \mathrm{O}\right]}+1},
$$

where $K_{1}, v_{1}$, and $K_{-1}$ are functions of temperature. The effective parameter, $B\left(\mathrm{O}_{2}^{+}\right)$, is proportional to $T^{-4.4}$ and depends on the $\mathrm{H}_{2} \mathrm{O}$ and $\mathrm{O}$ concentrations at any temperature.

The $\mathrm{NO}^{+}\left(\mathrm{H}_{2} \mathrm{O}\right)_{n}$ and $\mathrm{O}_{2}^{+}\left(\mathrm{H}_{2} \mathrm{O}\right)_{n}$ hydrated cluster ions, formed from the $\mathrm{NO}^{+}$and $\mathrm{O}_{2}^{+}$primary ions, were combined into a family Cluster ${ }_{1}^{+}\left(\mathrm{Cl}_{1}^{+}\right)$with the average recombination coefficient $\alpha_{\mathrm{Cl} 1+} \sim 2 \times 10^{-6} \mathrm{~cm}^{3} \mathrm{~s}^{-1}$ (Smirnova, 1982, 1983a, b; Smirnova and Vlaskov, 1982b). The complex proton hydrate formation process is described using a direct hydration reaction with the efficiency expressed as follows:

$$
B\left(\mathrm{Cl}_{1}^{+}\right)=10^{-27} \times(300 / T)^{4.4} \cdot\left[\mathrm{H}_{2} \mathrm{O}\right] \cdot\left[\mathrm{N}_{2}\right] .
$$

Because hydration processes are three-body collision processes with rates that depend on temperature, the effective parameter, $B\left(\mathrm{Cl}_{1}^{+}\right)$, depends on the temperature and $\mathrm{H}_{2} \mathrm{O}$ concentration. The $\mathrm{H}^{+}\left(\mathrm{H}_{2} \mathrm{O}\right)_{n}$ pure proton hydrates, forming from Cluster $_{1}^{+}$, are combined into a family Cluster ${ }_{2}^{+}\left(\mathrm{Cl}_{2}^{+}\right)$with the average recombination coefficient $\alpha_{\mathrm{Cl} 2+} \sim 1 \times 10^{-5} \mathrm{~cm}^{3} \mathrm{~s}^{-1}$ (Smirnova, 1982, 1983a, b; Smirnova and Vlaskov, 1982b). The expression for the efficiency of the channel transforming the $\mathrm{Cl}_{1}^{+}$family into $\mathrm{Cl}_{2}^{+}$ proton hydrates is derived via the evaluation and comparison of the formation rates and bond energies for $\mathrm{H}^{+}\left(\mathrm{H}_{2} \mathrm{O}\right)_{n-1} . X$ complex intermediate clusters (where $X$ is $\mathrm{N}_{2}$ or $\mathrm{CO}_{2}$ ). The $\mathrm{Cl}_{2}^{+}$ions recombine with electrons approximately five times faster than the $\mathrm{Cl}_{1}^{+}$ions.

Table 1 yields rate constants $\left(\mathrm{cm}^{3} \mathrm{~s}^{-1}\right)$ used in the $\mathrm{NO}^{+}$ and $\mathrm{O}_{2}^{+}$hydration channel efficiency expressions, recombination coefficients for $\mathrm{NO}^{+}$and $\mathrm{O}_{2}^{+}$with electrons and negative ions, and cluster ion dissociative recombination coefficients from Smirnova (1982, 1983a, b).

Ozone, atomic oxygen and nitric oxide participate in the complicated chemical transformation of the $\mathrm{O}_{2}^{-}$and $\mathrm{O}^{-}$primary negative ions into the $\mathrm{O}_{3}^{-}, \mathrm{O}_{4}^{-}, \mathrm{NO}_{2}^{-}$and $\mathrm{CO}_{4}^{-}$complex intermediate negative ions. These intermediate ions convert into each other very quickly via ion-molecule reactions. Although the ion concentrations are low, they are important for the formation of additional $\mathrm{CO}_{3}^{-}$and $\mathrm{NO}_{3}^{-}$stable ions. The efficiencies of the channels leading to $\mathrm{O}_{2}^{-}$and $\mathrm{O}^{-}$losses, $B\left(\mathrm{O}_{2}^{-}\right)$and $B\left(\mathrm{O}^{-}\right)$, during complex negative ion formation include the principal process rates from the detailed models by Arnold (1980) and Ferguson (1976) and are described as follows:

$$
\begin{aligned}
& B\left(\mathrm{O}_{2}^{-}\right)=\beta_{12} \cdot\left[\mathrm{O}_{2}\right]^{2}+\beta_{13} \cdot\left[\mathrm{O}_{2}\right] \cdot\left[\mathrm{CO}_{2}\right]+\beta_{14} \cdot\left[\mathrm{O}_{3}\right], \\
& B\left(\mathrm{O}^{-}\right)=\beta_{15} \cdot\left[\mathrm{O}_{2}\right]+\beta_{16} \cdot\left[\mathrm{O}_{2}\right] \cdot\left[\mathrm{CO}_{2}\right]+\beta_{17} \cdot\left[\mathrm{O}_{3}\right] .
\end{aligned}
$$

The reliability of the effective parameter expressions deduced for each channel have been verified via a comparison of the $\mathrm{NO}^{+}\left(\mathrm{H}_{2} \mathrm{O}\right), \mathrm{O}_{2}^{+}\left(\mathrm{H}_{2} \mathrm{O}\right), \mathrm{H}^{+}\left(\mathrm{H}_{2} \mathrm{O}\right)_{n}$ and $\mathrm{CO}_{3}^{-}$ formation rates calculated by both complex and simplified schemes.

The rate constants for the reactions that lead to the formation and loss of the $\mathrm{O}_{2}^{-}, \mathrm{O}^{-}, \mathrm{CO}_{3}^{-}$and $\mathrm{NO}_{3}^{-}$negative ions are presented in Table 2.

The algorithms for calculating solar radiation intensity for different wavelength ranges and ionisation rates, considering all ionisation sources during quiet periods, are presented in Barabash et al. (2012). The NRLMSISE-00 (Naval Research Laboratory Mass Spectrometer and Incoherent Scatter Radar) model of the atmosphere is used (Hedin, 1991; Picone et al., 2002).

The height profiles of the minor neutral constituents used in the model at local noon and midnight are implemented for calculations in the daytime ionosphere ( $\chi$ is less than 
Table 1. Rate constants $\left(\mathrm{cm}^{3} \mathrm{~s}^{-1}\right)$ included in the expressions for $\mathrm{NO}^{+}$and $\mathrm{O}_{2}^{+}$hydration channel efficiencies, recombination coefficients of $\mathrm{NO}^{+}$and $\mathrm{O}_{2}^{+}$with electrons and negative ions, and cluster ion dissociative recombination coefficients (from Smirnova, 1982, 1983a, b).

\begin{tabular}{ll}
\hline$r_{1}=1.8 \times 10^{-28}(300 / T)^{4.7}$ & $K_{1}=2.4 \times 10^{-30}(300 / T)^{3.2}$ \\
$r_{2}=2.0 \times 10^{-31}(300 / T)^{4.4}$ & $K_{-1}=1.8 \times 10^{-5}(300 / T)^{4.2} \exp (-5000 / T)$ \\
$r_{3}=1.0 \times 10^{-9}$ & $K_{2}=3.0 \times 10^{-10}$ \\
$r_{4}=1.0 \times 10^{-9}$ & $K_{3}=1.0 \times 10^{-10}$ \\
$r_{5}=7.0 \times 10^{-30}(300 / T)^{3.0}$ & $K_{4}=2.2 \times 10^{-9}$ \\
$r_{6}=1.0 \times 10^{-9}$ & $v_{1}=8.0 \times 10^{-31}(300 / T)^{4.4}$ \\
$r_{-2}=1.5 \times 10^{6} T^{-5.4} \exp (-450 / T)$ & $K_{5}=4.4 \times 10^{-10}$ \\
$r_{-5}=3.1 \times 10^{4} T^{-4.0} \exp (-4590 / T)$ & $K_{6}=1.0 \times 10^{-17}$ \\
$\alpha\left(\mathrm{NO}^{+}\right)=4.0 \times 10^{-7}(300 / T)$ & $\alpha\left(\mathrm{O}_{2}^{+}\right)=2.0 \times 10^{-7}(300 / T)$ \\
$\alpha\left(\mathrm{O}_{2}^{+}\right)=2.0 \times 10^{-7}(300 / T)$ & $\alpha_{\mathrm{i}}=6.8 \times 10^{-7} T^{-0.4}$ \\
$\alpha\left(\mathrm{Cl}_{1}^{+}\right)=2.0 \times 10^{-6}$ & $\alpha\left(\mathrm{Cl}_{2}^{+}\right)=1.0 \times 10^{-5}$ \\
\hline
\end{tabular}

$76^{\circ}$ ) and nighttime ionosphere ( $\chi$ is greater than $100^{\circ}$ ), respectively. To determine the altitude profiles of the minor species for solar zenith angles between 76 and $100^{\circ}$, twodimensional correction coefficient matrices for each species are used. The correction coefficients depend on the solar zenith angle and altitude and were derived from the simulated results of Shimazaki and Laird (1970), Turco and Sechrist (1972b), and Ogawa and Shimazaki (1975) for a $5 \mathrm{~km}$ vertical domain. In the PGI model, the vertical resolution is $1 \mathrm{~km}$. The final twilight profile for the entire altitude range is a combination of daytime and nighttime profiles. The correction factors deduced from the matrix coefficients, which are linearly interpolated to a fine $1 \mathrm{~km}$ vertical grid, are considered.

The model input parameters are date, local time, geomagnetic latitude, geographic coordinates, solar activity index $F_{10.7}$, temperature, and altitude profiles for $\mathrm{O}_{2}, \mathrm{~N}_{2}$ and minor neutral constituents (i.e. $\mathrm{NO}, \mathrm{O}, \mathrm{O}_{3}, \mathrm{H}_{2} \mathrm{O}, \mathrm{O}_{2}\left(1 \Delta_{\mathrm{g}}\right), \mathrm{NO}_{2}$ and $\mathrm{CO}_{2}$ ) for local noon and midnight with a vertical interval of $1 \mathrm{~km}$. The model solves a system of eight continuity equations for $\mathrm{O}_{2}^{+}, \mathrm{NO}^{+}, \mathrm{Cl}_{1}^{+}, \mathrm{Cl}_{2}^{+}, \mathrm{O}_{2}^{-}, \mathrm{O}^{-}, \mathrm{CO}_{3}^{-}$and $\mathrm{NO}_{3}^{-}$. Due to the short lifetimes of ions and electrons in the $\mathrm{D}$ region, the dynamical and transport effects are not considered. The electron number density, $N_{\mathrm{e}}$, is calculated as a difference between the positive and negative ion number densities. In photochemical equilibrium, the effective recombination coefficient is determined as follows (Rishbeth and Garriott, 1969; Danilov and Simonov, 1981):

$\alpha_{\mathrm{eff}}=(1+\lambda) \cdot\left(\alpha_{\mathrm{d}}+\lambda \alpha_{\mathrm{i}}\right)$,

$\alpha_{\mathrm{d}}=\left(\alpha_{\mathrm{NO}^{+}, \mathrm{O}_{2}^{+}}+f^{+} \cdot \alpha_{\mathrm{Cl}^{+}}\right) /\left(1+f^{+}\right)$,

where $\alpha_{\mathrm{d}}$ is the recombination coefficient weighted for different positive ion types and $\alpha_{\mathrm{i}}$ is the ion-ion recombination coefficient. The latter depends on the cluster ion formation rates or efficiency of the channels forming cluster ions, which then depends on the water vapour concentration and temperature.

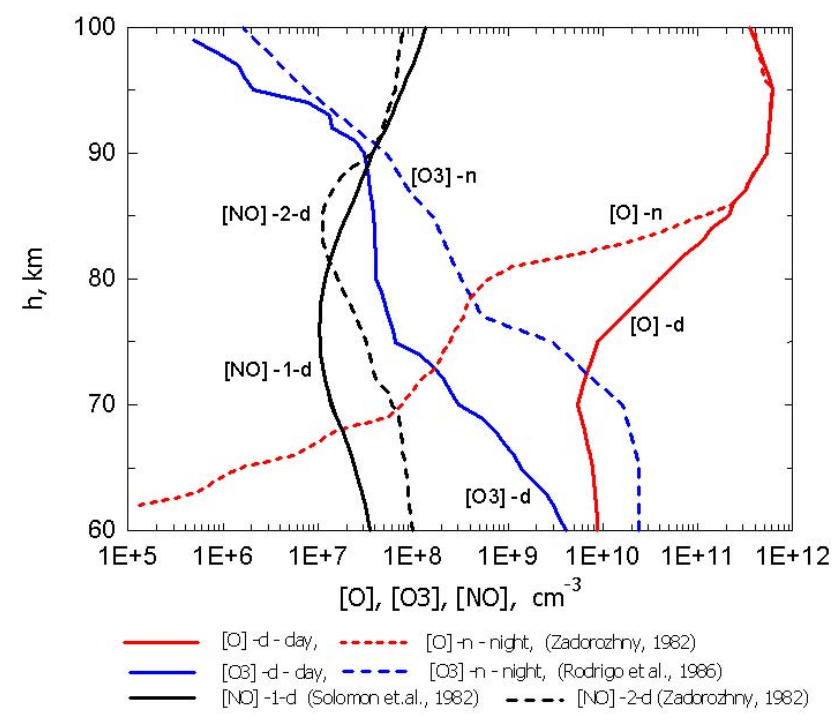

Fig. 1. Profiles of atomic oxygen, ozone and nitric oxide in the mesosphere used as model input parameters.

The minor neutral species are taken from the diffusion-photochemical models developed by Ogawa and Shimazaki (1975), Zadorozhny (1982), Solomon et al. (1982), and Rodrigo et al. (1986). Figure 1 presents the atomic oxygen $(\mathrm{O})$, ozone $\left(\mathrm{O}_{3}\right)$ and nitric oxide $(\mathrm{NO})$ profiles used as input parameters for our calculations. According to Barabash et al. (2012), the NO-1-d profile is applied for a low solar activity index (i.e. $F_{10.7}=70-120$ ) and the NO-2-d profile is used for $F_{10.7}>120$.

The applied model describes and explains (Danilov and Smirnova, 1993, 1994, 2003) changes in the $f^{+}$parameter, the transit height, $h_{f+=1}$, and $\alpha_{\text {eff }}$ caused by strong ionisation sources and calculated from measurements in various geophysical situations (Johannessen and Krankowsky, 1972; Arnold, 1980; Kopp et al., 1985; Krankowsky et al., 1987; Nacisi et al., 1971; Derblom and Laddel, 1973; Brekke et al., 1985). 
Table 2. Rate constants for the reactions leading to the formation and loss of the $\mathrm{O}_{2}^{-}, \mathrm{O}^{-}, \mathrm{CO}_{3}^{-}$and $\mathrm{NO}_{3}^{-}$negative ions in the $\mathrm{Smirnova}(1982$, 1983a, b) chemical scheme.

\begin{tabular}{|c|c|}
\hline Reaction & Rate constant \\
\hline $\begin{array}{l}\text { 1.e } e+\mathrm{O}_{2}+\mathrm{O}_{2} \rightarrow \mathrm{O}_{2}^{-}+\mathrm{O}_{2} \\
\text { 2.e } e+\mathrm{O}_{2}+\mathrm{N}_{2} \rightarrow \mathrm{O}_{2}^{-}+\mathrm{N}_{2} \\
\text { 3. } \mathrm{O}_{2}^{-}+\mathrm{O}\left({ }^{3} \mathrm{P}\right) \rightarrow e+\mathrm{O}_{3} \\
\text { 4. } \mathrm{O}_{2}^{-}+\mathrm{O}_{2}\left({ }^{1} \Delta \mathrm{g}\right) \rightarrow e+\mathrm{O}_{2}+\mathrm{O}_{2} \\
\text { 5. } e+\mathrm{O}_{3} \rightarrow \mathrm{O}^{-}+\mathrm{O}_{2} \\
\text { 6. } \mathrm{O}^{-}+\mathrm{O} \rightarrow e+\mathrm{O}_{2} \\
\text { 7. } \mathrm{O}^{-}+\mathrm{O}_{2}\left({ }^{1} \Delta \mathrm{g}\right) \rightarrow e+\mathrm{O}_{3} \\
\text { 8. } \mathrm{CO}_{3}^{-}+\mathrm{O}\left({ }^{3} \mathrm{P}\right) \rightarrow \mathrm{O}_{2}^{-}+\mathrm{CO}_{2} \\
\text { 9. } \mathrm{CO}_{3}^{-}+h v=\mathrm{O}^{-}+\mathrm{CO}_{2} \\
\text { 10. } \mathrm{CO}_{3}^{-}+\mathrm{NO}^{-} \mathrm{NO}_{2}^{-}+C O_{2} \\
\text { 11. } \mathrm{CO}_{3}^{-}+\mathrm{NO}_{2} \rightarrow \mathrm{NO}_{3}^{-}+\mathrm{CO}_{2} \\
\text { 12. } \mathrm{O}_{2}^{-}+\mathrm{O}_{2}+\mathrm{O}_{2} \rightarrow \mathrm{O}_{4}^{-}+\mathrm{O}_{2} \\
\text { 13. } \mathrm{O}_{2}^{-}+\mathrm{CO}_{2}+\mathrm{O}_{2} \rightarrow \mathrm{CO}_{4}^{-}+\mathrm{O}_{2} \\
\text { 14. } \mathrm{O}_{2}^{-}+\mathrm{O}_{3} \rightarrow \mathrm{O}_{3}^{-}+\mathrm{O}_{2} \\
\text { 15. } \mathrm{O}^{-}+\mathrm{O}_{2}+\mathrm{O}_{2} \rightarrow \mathrm{O}_{3}^{-}+\mathrm{O}_{2} \\
\text { 16. } \mathrm{O}^{-}+\mathrm{CO}_{2}+\mathrm{O}_{2} \rightarrow \mathrm{CO}_{3}^{-}+\mathrm{O}_{2} \\
\text { 17. } \mathrm{O}^{-}+\mathrm{O}_{3} \rightarrow \mathrm{O}_{3}^{-}+\mathrm{O} \\
\text { 18. } \mathrm{O}_{2}^{-}+h v \rightarrow e+\mathrm{O}_{2} \\
\text { 19. } \mathrm{O}^{-}+h v \rightarrow e+\mathrm{O} \\
\text { 20. } \mathrm{NO}_{3}^{-}+h v=e+\mathrm{NO}_{3} \\
\text { 21. } \alpha_{\mathrm{i}}\left[\mathrm{N}^{+}\right]\left[\mathrm{O}^{-}\right] \\
\text {22. } \alpha_{\mathrm{i}}\left[\mathrm{N}^{+}\right]\left[\mathrm{CO}_{3}^{-}\right] \\
\text {23. } \alpha_{\mathrm{i}} \mathrm{N}^{+}\left[\mathrm{O}_{2}^{-}\right] \\
\text {24. } \alpha_{\mathrm{i}} \mathrm{N}^{+}\left[\mathrm{O}^{-}\right] \\
\text {25. } \alpha_{\mathrm{i}} \mathrm{N}^{+}\left[\mathrm{CO}_{3}^{-}\right] \\
\text {26. } \alpha_{\mathrm{i}} \mathrm{N}^{+}\left[\mathrm{NO}_{3}^{-}\right]\end{array}$ & $\begin{array}{l}\beta_{1}=1.4 \times 10^{-29}(300 / T) \exp (-600 / T) \\
\beta_{2}=1.0 \times 10^{-31} \\
\beta_{3}=1.5 \times 10^{-10} \\
\beta_{4}=2.0 \times 10^{-10} \\
\beta_{5}=9.1 \times 10^{-12}(300 / T)^{-1.46} \\
\beta_{6}=1.9 \times 10^{-10} \\
\beta_{7}=2.0 \times 10^{-10} \\
\beta_{8}=1.1 \times 10^{-10} \\
\beta_{9}=0.15 \mathrm{~s}^{-1} \\
\beta_{10}=1.1 \times 10^{-10} \\
\beta_{11}=2.0 \times 10^{-10} \\
\beta_{12}=4.0 \times 10^{-31}(300 / T)^{5.0} \\
\beta_{13}=2.0 \times 10^{-29}(300 / T)^{5.0} \\
\beta_{14}=6.0 \times 10^{-10} \\
\beta_{15}=9.0 \times 10^{-31}(300 / T)^{5.0} \\
\beta_{16}=3.1 \times 10^{-28}(300 / T)^{5.0} \\
\beta_{17}=5.3 \times 10^{-10} \\
\rho_{1}=0.33 \mathrm{~s}^{-1} \\
\rho_{2}=1.4 \mathrm{~s}^{-1} \\
\rho_{3}=1.5 \times 10^{-3} \mathrm{~s}^{-1} \\
\alpha_{\mathrm{i}}=6.8 \times 10^{-7} T^{-0.4} \\
\alpha_{\mathrm{i}}=6.8 \times 10^{-7} T^{-0.4} \\
\alpha_{\mathrm{i}}=6.8 \times 10^{-7} T^{-0.4} \\
\alpha_{\mathrm{i}}=6.8 \times 10^{-7} T^{-0.4} \\
\alpha_{\mathrm{i}}=6.8 \times 10^{-7} T^{-0.4} \\
\alpha_{\mathrm{i}}=6.8 \times 10^{-7} T^{-0.4}\end{array}$ \\
\hline
\end{tabular}

Model verification is based on the comparison of the modelled electron density profiles with several electron density profiles measured by the European Incoherent Scatter (EISCAT) radar during auroral absorption and solar proton events (Vlaskov et al., 1990; Kirkwood et al., 2001; Osepian et al., 2009a) and during rocket flights in the quiet ionosphere at mid-latitudes (Barabash et al., 2012).

Water is one of the most important species in the lower ionosphere and is characterised by strong spatial and temporal variability. Pronounced daily water variability is connected to planetary wave activity throughout the year (Hartogh et al., 2010). The largest water vapour concentrations have been found during summer because of intensified gravity wave upward propagation. Between 65 and $75 \mathrm{~km}$, an additional water vapour maximum has been observed due to the interaction between upward motions and autocatalytic water vapour formation (Sonnemann et al., 2005, 2012). Satellite measurements performed during the Middle Atmosphere High-Resolution Spectrograph Investigation indicated a water vapour peak between 10 and $15 \mathrm{ppmv}$ at altitudes between 82 and $84 \mathrm{~km}$ in the polar summer mesosphere (Summers et al., 2001). Data from the Odin satellite give an average peak of 8 ppmv at $80 \mathrm{~km}$ for July in high latitudes, i.e. north of $55^{\circ} \mathrm{N}$ (Lossow et al., 2007). Measurements from the HALOE (Halogen Occultation Experiment) with the Upper Atmosphere Research Satellite (UARS) also exhibit large water profile variability between 60 and $100 \mathrm{~km}$ (http://haloe.gats-inc.com/home/index.php). The water vapour profiles measured with the HALOE instrument aboard the UARS on 25 January 2004, 4 June 2005 and 19 June 2004 are applied in this study. The $\mathrm{H}_{2} \mathrm{O}-1, \mathrm{H}_{2} \mathrm{O}-2$, and $\mathrm{H}_{2} \mathrm{O}-3$ profiles are presented in Fig. 2. The deviations between profiles 1 and 2 produce maximum values, i.e. a factor of 12 , between 82 and $84 \mathrm{~km}$. The $\mathrm{H}_{2} \mathrm{O}-3$ profile is an artificially modified $\mathrm{H}_{2} \mathrm{O}-1$ profile with the number densities that increase between 75 and $87 \mathrm{~km}$ relative to the $\mathrm{H}_{2} \mathrm{O}-1$ profile. 


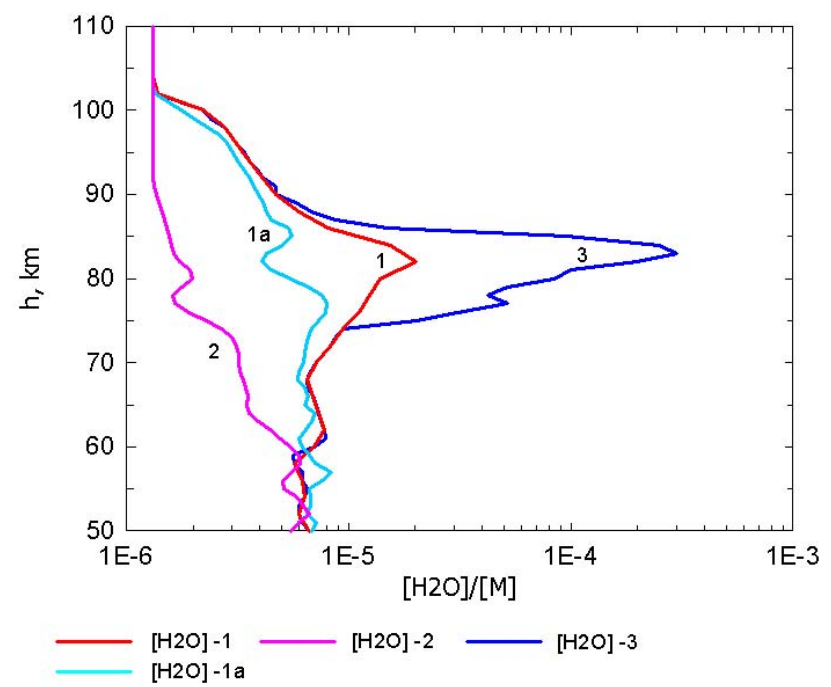

Fig. 2. Water vapour profiles in ppmv in the mesosphere used as input parameters for calculations. Experimental profiles $\mathrm{H}_{2} \mathrm{O}-1, \mathrm{H}_{2} \mathrm{O}$ $1 \mathrm{a}$, and $\mathrm{H}_{2} \mathrm{O}-2$ were retrieved from the HALOE measurements on 19 June $2004\left(\mathrm{H}_{2} \mathrm{O}-1\right)$, 4 June $2005\left(\mathrm{H}_{2} \mathrm{O}-1 \mathrm{a}\right)$ and 25 January 2004 $\left(\mathrm{H}_{2} \mathrm{O}-2\right)$.

\section{Results}

\subsection{Effect of the water vapour concentration on channel efficiencies for $\mathrm{NO}^{+} \rightarrow \mathrm{NO}^{+} . \mathrm{H}_{2} \mathrm{O}$ and Cluster $_{1}^{+} \rightarrow$ Cluster $_{2}^{+}$}

Figure 3a compares height profiles of the efficiency for the $\mathrm{NO}^{+} \rightarrow \mathrm{NO}^{+} . \mathrm{H}_{2} \mathrm{O}$ channel, $B\left(\mathrm{NO}^{+}\right)$, calculated for winter and summer based on the $\mathrm{H}_{2} \mathrm{O}-1$ and $\mathrm{H}_{2} \mathrm{O}-2$ profiles. Dashed curves 1 and 2 show height profiles for the efficiency of $\mathrm{NO}^{+}$ion direct hydration. Above $60 \mathrm{~km}$, the direct hydration efficiency strongly decreases and the $\mathrm{NO}^{+} . \mathrm{H}_{2} \mathrm{O}$ cluster form primarily via indirect hydration. The water concentration growth between 60 and $100 \mathrm{~km}$, e.g. from the $\mathrm{H}_{2} \mathrm{O}-2$ to the $\mathrm{H}_{2} \mathrm{O}-1$ profile (by a factor of $2-2.5$ between 65 and $70 \mathrm{~km}$, by a factor of 4.4 at $75 \mathrm{~km}$ and by a factor of $10-12$ between 82 and $84 \mathrm{~km}$ ), increases the $\mathrm{NO}^{+}$indirect hydration efficiency in summer below $82 \mathrm{~km}$ (by a factor of 1.951.75 between 65 and $70 \mathrm{~km}$ and by a factor of 1.4 at $75 \mathrm{~km}$ ). In winter, $B\left(\mathrm{NO}^{+}\right)$increases at all altitudes in conjunction with the increasing $\mathrm{H}_{2} \mathrm{O}$ concentrations.

Figure $3 \mathrm{~b}$ compares the efficiency of a channel transforming $\mathrm{Cl}_{1}^{+}$into $\mathrm{Cl}_{2}^{+}$with $B\left(\mathrm{NO}^{+}\right)$. In the lower part of the D region, i.e. below $70 \mathrm{~km}, B\left(\mathrm{Cl}_{1}^{+}\right)$is always larger than $B\left(\mathrm{NO}^{+}\right)$. Figure $4 \mathrm{a}$ and $\mathrm{b}$ present seasonal variations in the efficiency of the $\mathrm{NO}^{+} \rightarrow \mathrm{NO}^{+} . \mathrm{H}_{2} \mathrm{O}$ channel, $B\left(\mathrm{NO}^{+}\right)$, calculated at 75 and $80 \mathrm{~km}$ and the $\mathrm{Cl}_{1}^{+} \rightarrow \mathrm{Cl}_{2}^{+}$channel, $B\left(\mathrm{Cl}_{1}^{+}\right)$, at $75 \mathrm{~km}$ for the $\mathrm{H}_{2} \mathrm{O}-1$ and $\mathrm{H}_{2} \mathrm{O}-2$ profiles. It is clear that the seasonal $B\left(\mathrm{NO}^{+}\right)$and $B\left(\mathrm{Cl}_{1}^{+}\right)$variations are primarily associated with seasonal neutral mesospheric temperature variations (winter temperature is higher than

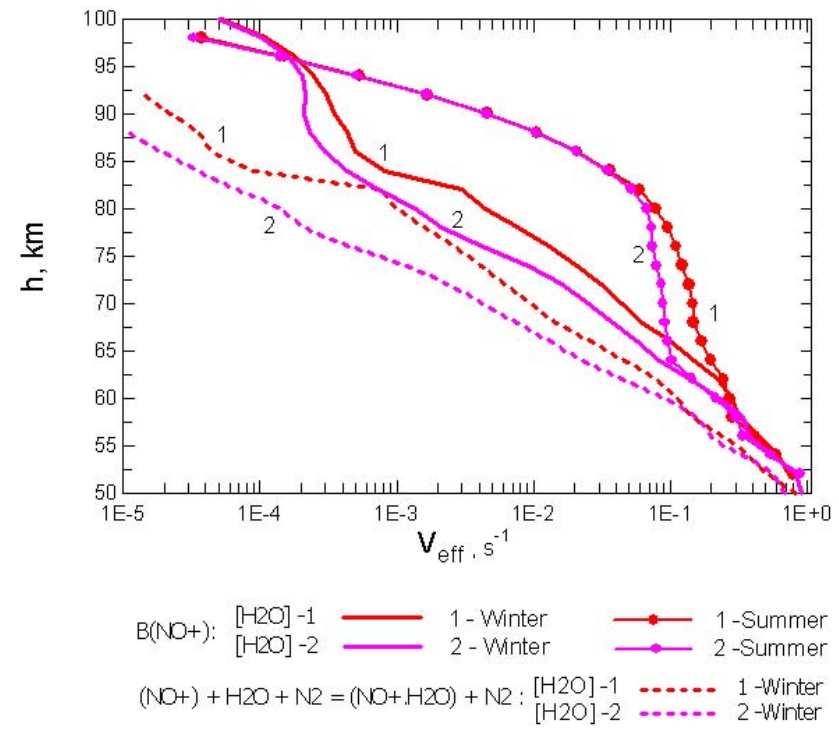

Fig. 3a. Efficiency of the $\mathrm{NO}^{+} \rightarrow \mathrm{NO}^{+} \cdot \mathrm{H}_{2} \mathrm{O}$ channel, $B\left(\mathrm{NO}^{+}\right)$, calculated for winter and summer based on the $\mathrm{H}_{2} \mathrm{O}-1$ and $\mathrm{H}_{2} \mathrm{O}-$ 2 profiles. Dashed curves 1 and 2 show the vertical profiles of the efficiency for $\mathrm{NO}^{+}$ion direct hydration.

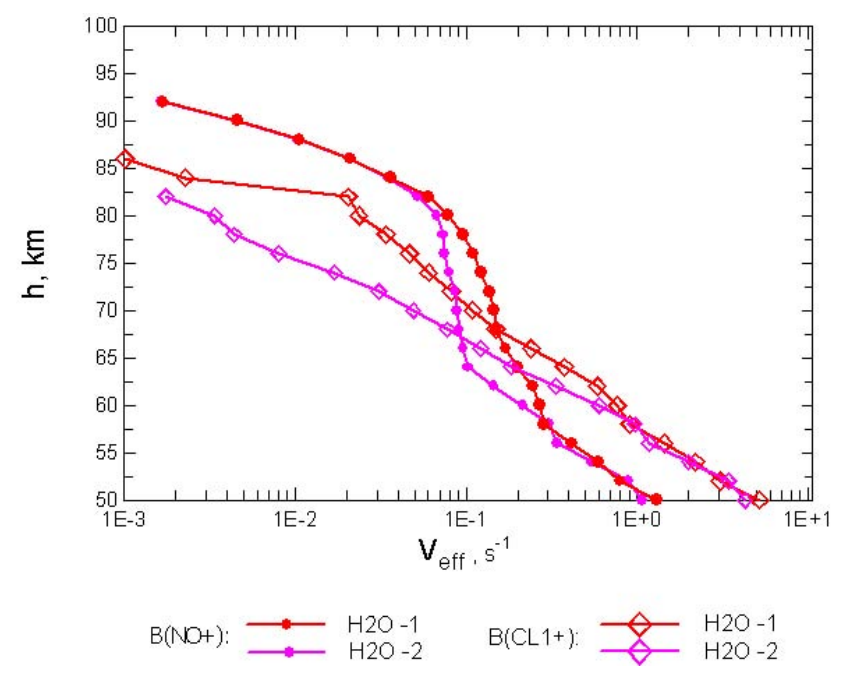

Fig. 3b. $B\left(\mathrm{NO}^{+}\right)$and $B\left(\mathrm{Cl}_{1}^{+}\right)$efficiencies calculated for winter and summer based on the $\mathrm{H}_{2} \mathrm{O}-1$ and $\mathrm{H}_{2} \mathrm{O}-2$ profiles.

summer temperature). The larger variability in $B\left(\mathrm{NO}^{+}\right)$ compared with $B\left(\mathrm{Cl}_{1}^{+}\right)$is due to the stronger inverse temperature dependence of $B\left(\mathrm{NO}^{+}\right)$. The water vapour concentration effect on $B\left(\mathrm{NO}^{+}\right)$is more pronounced at higher temperatures; i.e. it is stronger in winter than in summer. Above the summer mesopause, i.e. above $82 \mathrm{~km}$, the temperature is the primary factor that affects the $\mathrm{NO}^{+}$hydration channel efficiency. 


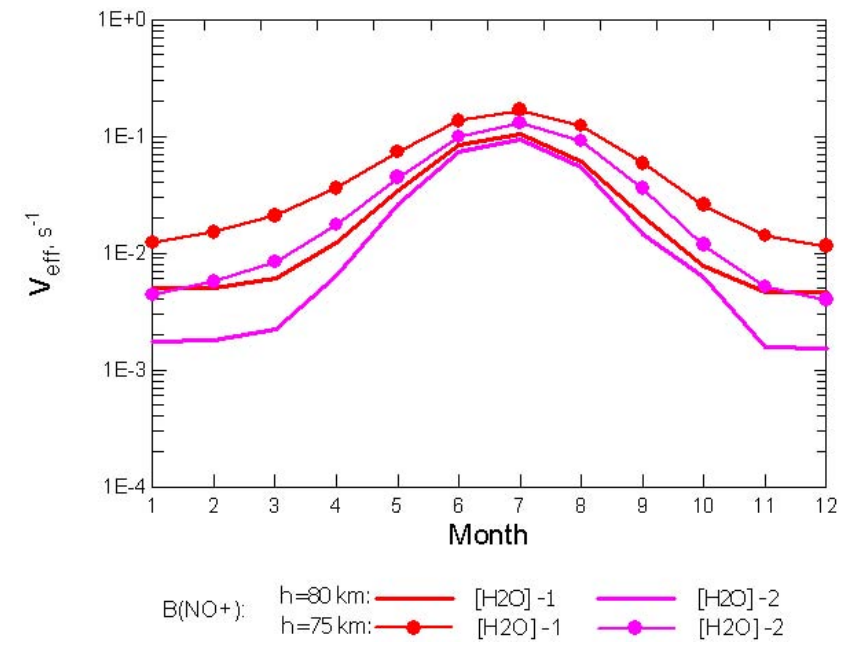

Fig. 4a. Seasonal variation in the $B\left(\mathrm{NO}^{+}\right)$efficiency calculated based on the $\mathrm{H}_{2} \mathrm{O}-1$ and $\mathrm{H}_{2} \mathrm{O}-2$ profiles for 75 and $80 \mathrm{~km}$.

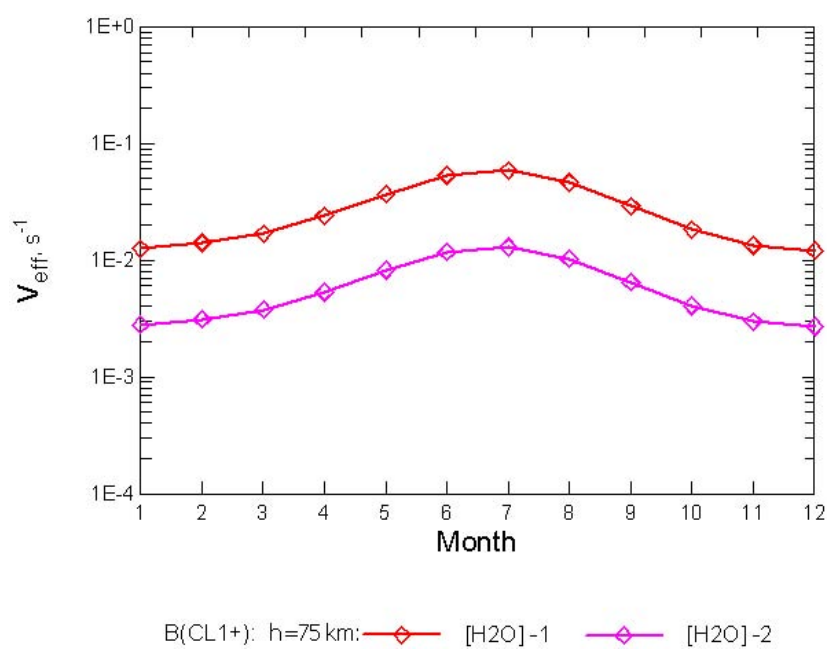

Fig. 4b. Seasonal variation in the $B\left(\mathrm{Cl}_{1}^{+}\right)$efficiency calculated based on the $\mathrm{H}_{2} \mathrm{O}-1$ and $\mathrm{H}_{2} \mathrm{O}-2$ profiles for $75 \mathrm{~km}$.

\subsection{Case: 16 June 2004}

Figure 5a, b and c show the water vapour effect on electron and positive ion height distributions. The electron number density measured by the EISCAT radar on 16 June 2004 at 12:00 UT for $\chi=47.3^{\circ}$ and $F_{10.7}=110$ in northern Sweden $\left(69.6^{\circ} \mathrm{N}, 19.3^{\circ} \mathrm{E}\right)$ is shown in black. Modelled profiles have been calculated for NO-1-d and the $\mathrm{H}_{2} \mathrm{O}-1, \mathrm{H}_{2} \mathrm{O}-2$ and $\mathrm{H}_{2} \mathrm{O}-3$ profiles. The model results agree well with the observations. However, at lower altitudes, the measured electron density fluctuates. This finding is likely due to receiver noise that increases at lower altitudes with decreasing electron number density.

Figure $5 \mathrm{~b}$ and $\mathrm{c}$ show how different water vapour profiles can modify positive ion number density and redistribute

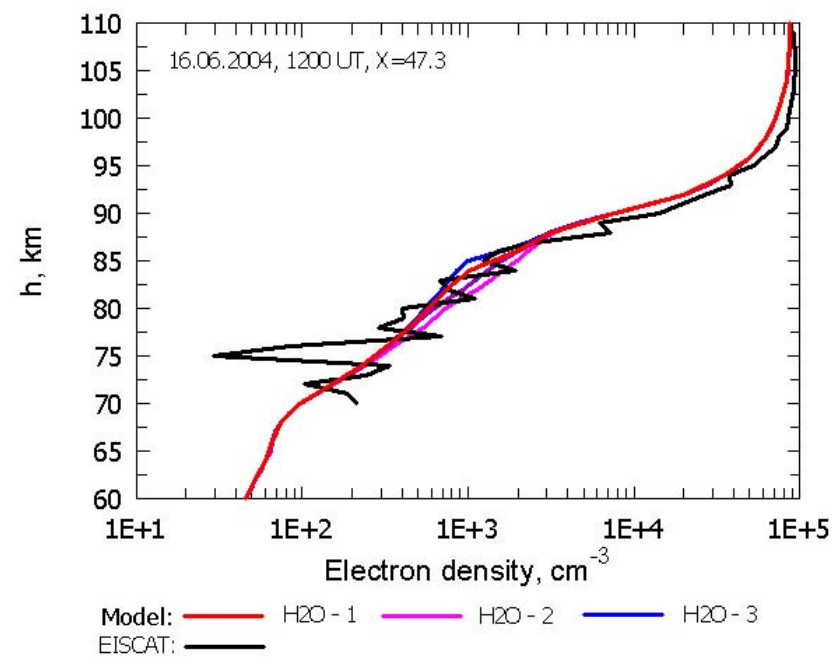

Fig. 5a. Electron density profiles for 16 June 2004 at 12:00 UT. The black line corresponds to the electron density profile measured by the EISCAT radar; red, violet and blue lines correspond to the electron density profiles calculated for the $\mathrm{H}_{2} \mathrm{O}-1, \mathrm{H}_{2} \mathrm{O}-2$ and $\mathrm{H}_{2} \mathrm{O}-3$ profiles, respectively.

the ion composition. The vertical layer with $\mathrm{Cl}_{2}^{+}$proton hydrates expands upward and the $\mathrm{Cl}_{2}^{+}$number density between 75 and $87 \mathrm{~km}$ increases when water concentration increases. The maximum $\mathrm{Cl}_{2}^{+}$concentration height progressively increases from $80 \mathrm{~km}$ for $\mathrm{H}_{2} \mathrm{O}-2$ to $85 \mathrm{~km}$ for $\mathrm{H}_{2} \mathrm{O}-3$. The upper $\mathrm{Cl}_{2}^{+}$bound, with a numerical density of $100 \mathrm{~cm}^{-3}$, is located between 85 and $88 \mathrm{~km}$. A similar pattern, albeit less pronounced, is found for $\mathrm{Cl}_{2}^{+}$with a concentration of $10 \mathrm{~cm}^{-3}$. Therefore, the water vapour concentration increase in the entire mesosphere (transition from the $\mathrm{H}_{2} \mathrm{O}-2$ profile to the $\mathrm{H}_{2} \mathrm{O}-1$ and $\mathrm{H}_{2} \mathrm{O}-3$ profiles) leads to a reduction in the $\mathrm{Cl}_{1}^{+}$ layer altitude range by shifting the $\mathrm{Cl}_{1}^{+}$layer lower border upward. For $\mathrm{Cl}_{1}^{+}$, with a concentration of $10 \mathrm{~cm}^{-3}$, the lower border rises from $72.5 \mathrm{~km}$ to $75 \mathrm{~km}$ and $78 \mathrm{~km}$. The lowest $\mathrm{Cl}_{1}^{+}$borders for with $100 \mathrm{~cm}^{-3}$ are located at $76.5,81.5$ and $85 \mathrm{~km}$. The $\mathrm{Cl}_{1}^{+}$layer upper border for a given numerical density does not depend on the water vapour concentration. Specifically, the border is located at $96 \mathrm{~km}$ for $\mathrm{Cl}_{1}^{+}=10 \mathrm{~cm}^{-3}$

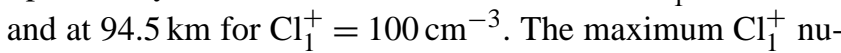
merical density is also independent of the water vapour concentration and is located near $89 \mathrm{~km}$. The decrease in the $\mathrm{NO}^{+}$and $\mathrm{O}_{2}^{+}$molecular ion number densities below $87 \mathrm{~km}$ is caused by the increased water vapour concentration (Fig. 5c).

Figure 6a shows the altitude distribution for the $f^{+}$and $\lambda$ parameters. The transit altitude for positive ions, $h_{f+=1}$, is located at approximately $89 \mathrm{~km}$ for any water vapour concentration. There are also deviations between $f^{+}$altitude profiles for different water vapour concentrations below $87 \mathrm{~km}$. The $\lambda$ altitude profile is the same for all water profiles; the $h_{\lambda=1}$ transit altitude is located at approximately $67 \mathrm{~km}$. 


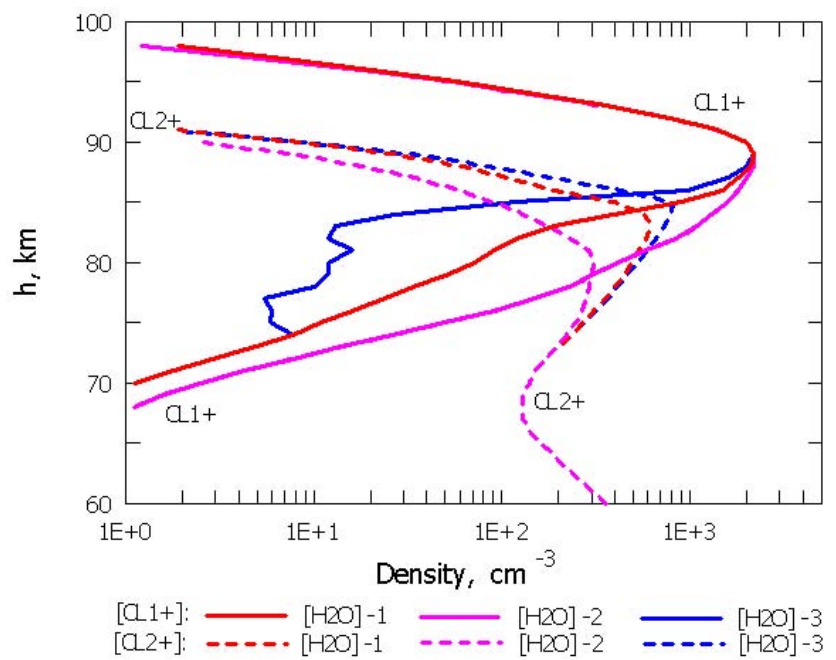

Fig. 5b. Number density profiles for the $\mathrm{Cl}_{1}^{+}$and $\mathrm{Cl}_{2}^{+}$positive ions cluster families for 16 June 2004 at 12:00 UT, with a solar zenith angle of $47.3^{\circ}$ and calculated for the $\mathrm{H}_{2} \mathrm{O}-1, \mathrm{H}_{2} \mathrm{O}-2$ and $\mathrm{H}_{2} \mathrm{O}-3$ profiles.

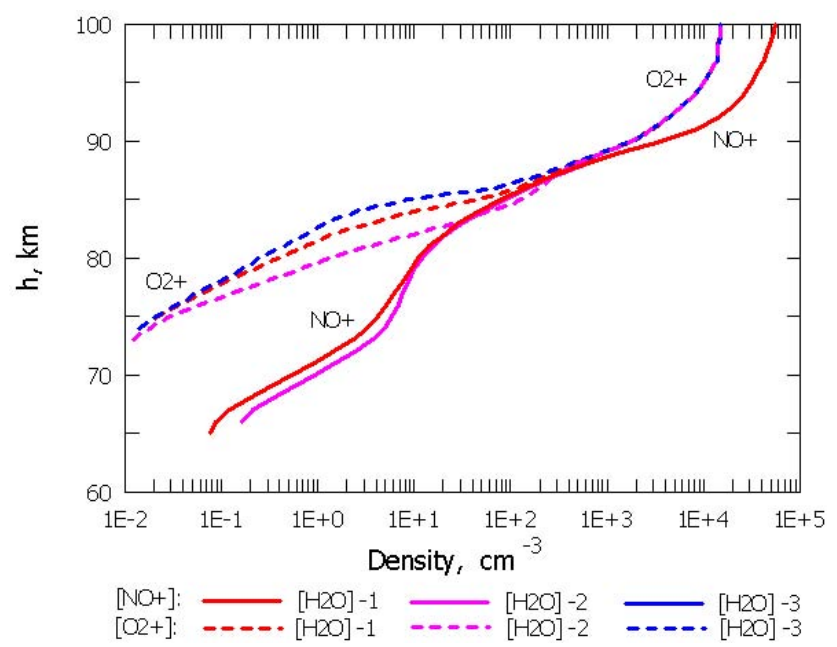

Fig. 5c. Number density profiles for the $\mathrm{O}_{2}^{+}$and $\mathrm{NO}^{+}$molecular ions for 16 June 2004 at 12:00 UT, with a solar zenith angle of $47.3^{\circ}$ and calculated for the $\mathrm{H}_{2} \mathrm{O}-1, \mathrm{H}_{2} \mathrm{O}-2$ and $\mathrm{H}_{2} \mathrm{O}-3$ profiles.

Variations in the effective recombination coefficient, $\alpha_{\text {eff }}$, caused by changes in the water vapour concentration are shown in Fig. 6b. As shown in Fig. 5b, if the water concentration is low $\left(\mathrm{H}_{2} \mathrm{O}-2\right)$, the $\mathrm{Cl}_{2}^{+}$ions are dominant only up to $78 \mathrm{~km}$ (violet curve in Fig. 5b). Between $78 \mathrm{~km}$ and $87 \mathrm{~km}$, the $\mathrm{Cl}_{1}^{+}$hydrate cluster ions become dominant. In this situation, the effective recombination coefficient, $\alpha_{\text {eff }}$, decreases from $1.2 \times 10^{-5} \mathrm{~cm}^{-3} \mathrm{~s}^{-1}$ at $75 \mathrm{~km}$, i.e. closer to the dissociative recombination coefficient of $\mathrm{Cl}_{2}^{+}$, to $2.0 \times 10^{-6} \mathrm{~cm}^{-3} \mathrm{~s}^{-1}$ at $87 \mathrm{~km}$, i.e. closer to the dissociative recombination coefficient of $\mathrm{Cl}_{1}^{+}$(violet curve in Fig. 6b). Using the $\mathrm{H}_{2} \mathrm{O}-1$ profile results in the dominance of $\mathrm{Cl}_{2}^{+}$proton hydrates over a

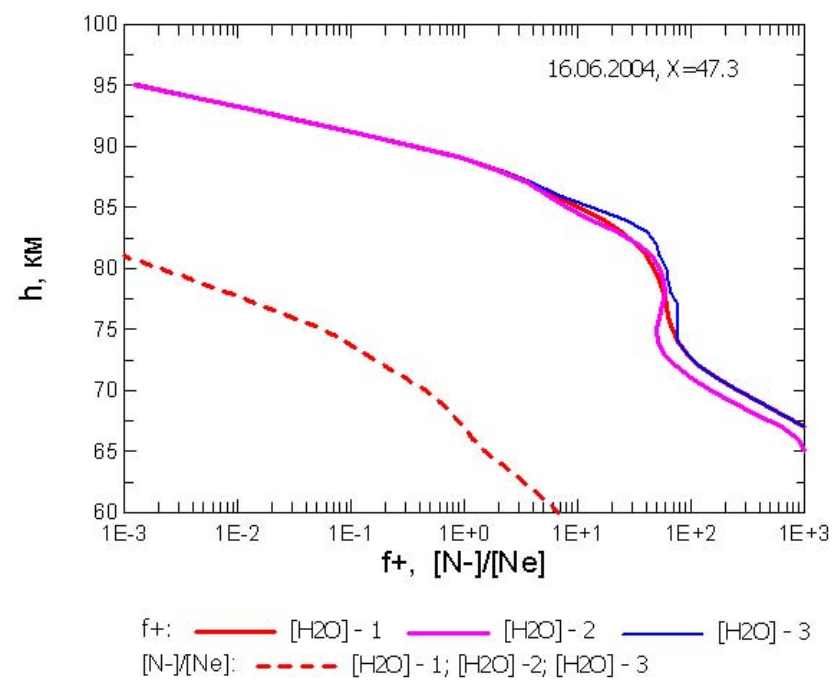

Fig. 6a. Profiles for $f^{+}$(solid lines) and $\lambda=N^{-} / N_{e}$ (dashed line) for 16 June 2004 at 12:00 UT, with a solar zenith angle of $47.3^{\circ}$ and calculated for $\mathrm{H}_{2} \mathrm{O}-1, \mathrm{H}_{2} \mathrm{O}-2$ and $\mathrm{H}_{2} \mathrm{O}-3$ profiles.

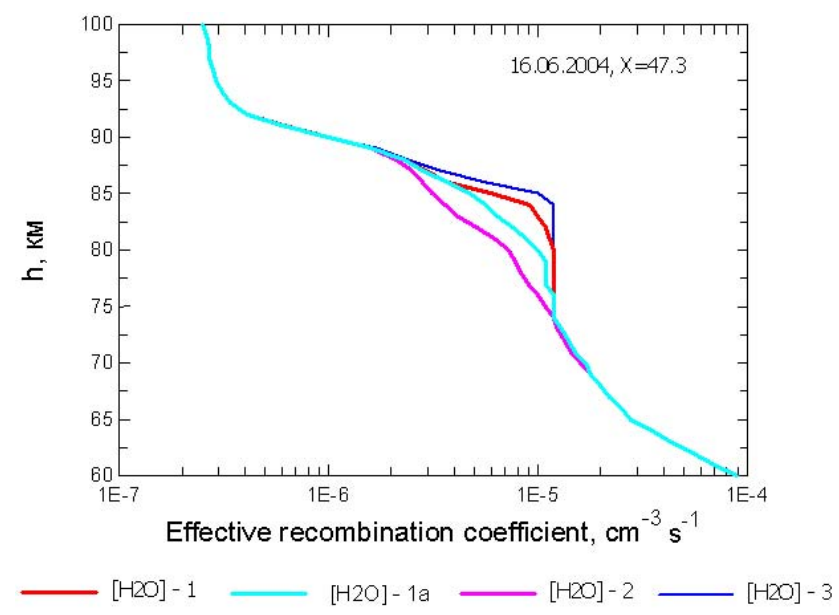

Fig. 6b. Effective recombination coefficient profiles for 16 June 2004 at 12:00 UT, with a solar zenith angle of $47.3^{\circ}$ and calculated for the $\mathrm{H}_{2} \mathrm{O}-1, \mathrm{H}_{2} \mathrm{O}-1 \mathrm{a}, \mathrm{H}_{2} \mathrm{O}-2$ and $\mathrm{H}_{2} \mathrm{O}-3$ profiles presented in Fig. 2.

broader altitude interval; the effective recombination coefficient, $\alpha_{\text {eff }}$, is approximately $1.2 \times 10^{-5} \mathrm{~cm}^{-3} \mathrm{~s}^{-1}$, i.e. close to the dissociative recombination coefficient of $\mathrm{Cl}_{2}^{+}$, at the altitudes up to $82 \mathrm{~km}$ (red curves in Figs. $5 \mathrm{~b}$ and $6 \mathrm{~b}$ ). An increase in the water vapour concentration by approximately an order of magnitude compared to the $\mathrm{H}_{2} \mathrm{O}-2$ profile at $84 \mathrm{~km}$ increases the $\mathrm{Cl}_{2}^{+}$number density by a factor of 4.5 . The effective recombination coefficient increases by a factor of 2.55 , from $3.6 \times 10^{-6} \mathrm{~cm}^{-3} \mathrm{~s}^{-1}$ to $9.2 \times 10^{-6} \mathrm{~cm}^{-3} \mathrm{~s}^{-1}$, and the electron number density decreases by a factor of 1.6 (red curve in Fig. 5a). However, the subsequent large increase in water vapour concentration between 75 and $87 \mathrm{~km}$ (using the 


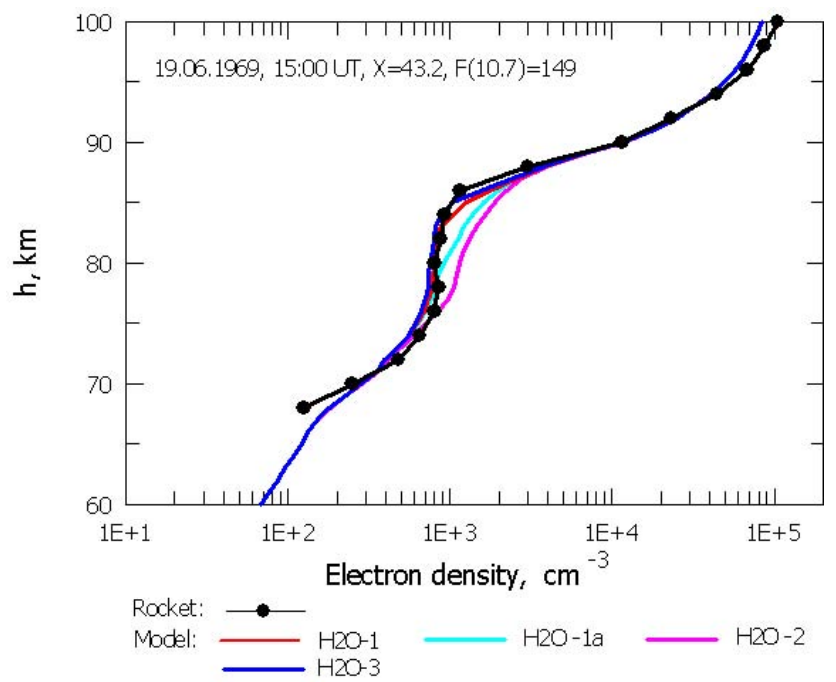

Fig. 7a. Electron density profiles for 19 June 1969 at 15:00 UT, with $\chi=43.2^{\circ}$ and $F_{10.7}=149$, as measured by the rocket (black dotted line) and calculated for $\mathrm{H}_{2} \mathrm{O}-1, \mathrm{H}_{2} \mathrm{O}-1 \mathrm{a}, \mathrm{H}_{2} \mathrm{O}-2$ and $\mathrm{H}_{2} \mathrm{O}-3$ profiles presented in Fig. 2.

$\mathrm{H}_{2} \mathrm{O}-3$ profile) leads to only minor changes in the $\mathrm{Cl}_{2}^{+}$number density, occurring only within a very narrow interval between 82 and $86 \mathrm{~km}$ (blue curve in Fig. 5b). Water vapour concentration increases by a factor of 10 at $82 \mathrm{~km}$ and by a factor of 16 at $84 \mathrm{~km}$ relative to the $\mathrm{H}_{2} \mathrm{O}-1$ profile, while the $\mathrm{Cl}_{2}^{+}$number density increases by only 10 and $30 \%$, respectively. Inside this narrow vertical interval, the effective recombination coefficient increases again to approximately $1.2 \times 10^{-5} \mathrm{~cm}^{-3} \mathrm{~s}^{-1}$. Above $85 \mathrm{~km}$, the effective recombination coefficient sharply decreases (a blue curve in Fig. 6b). Therefore, only minor changes in the electron number density (approximately $10 \%$ ) occur between 82 and $86 \mathrm{~km}$ (blue curve in Fig. 5a). The modelling results show that there is an upper limit for water vapour concentration above which the effect of water vapour on the $\mathrm{Cl}_{2}^{+}$number density, the effective recombination coefficient and electron density between 75 and $87 \mathrm{~km}$ ceases.

\subsection{Case: 19 June 1969}

The electron density profile measured by a rocket on 19 June $1969\left(57.2^{\circ} \mathrm{N},-7.14^{\circ} \mathrm{E}, 15: 00 \mathrm{UT}, \chi=41.4^{\circ}\right.$, $F_{10.7}=150$ ) is shown in Fig. 7a (black curve). Electron density profiles have been modelled with NO-2d and all water vapour profiles presented in Fig. 2. The electron density profiles calculated with the $\mathrm{H}_{2} \mathrm{O}-1$ and $\mathrm{H}_{2} \mathrm{O}-3$ profiles are closer to the experimental electron density profile at all altitudes. Moreover, electron number density variations associated with differences between the $\mathrm{H}_{2} \mathrm{O}-1$ and $\mathrm{H}_{2} \mathrm{O}-3$ profiles do not exceed $10 \%$ at altitudes between 80 and $85 \mathrm{~km}$.

Altitude profiles of $\mathrm{Cl}_{1}^{+}$and $\mathrm{Cl}_{2}^{+}$number densities and $\alpha_{\text {eff }}$ for different water vapour concentrations are shown

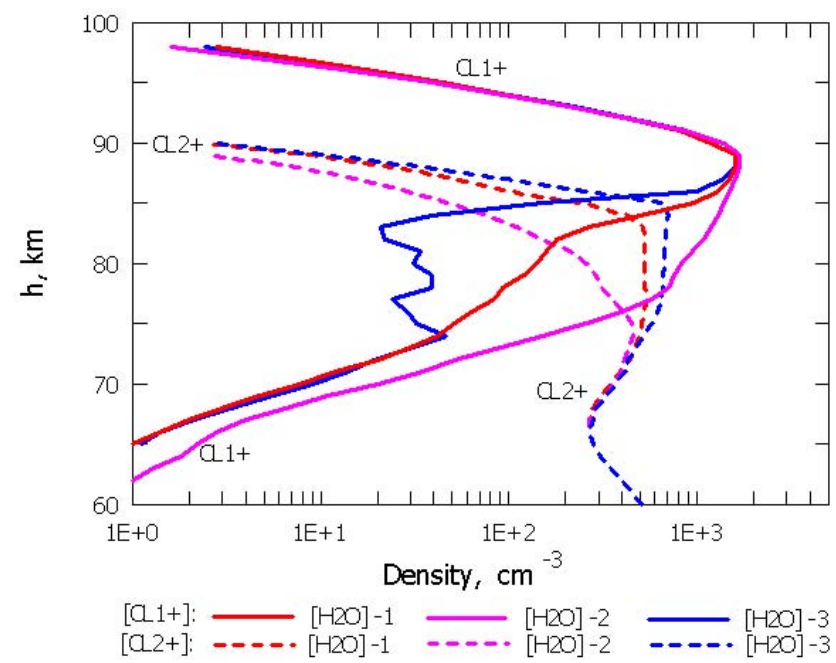

Fig. 7b. Number density profiles for the $\mathrm{Cl}_{1}^{+}$and $\mathrm{Cl}_{2}^{+}$positive ions cluster families for 19 June 1969 at 15:00 UT, with a solar zenith angle of $43.2^{\circ}, F_{10.7}=149$, and calculated for the $\mathrm{H}_{2} \mathrm{O}-1, \mathrm{H}_{2} \mathrm{O}-2$ and $\mathrm{H}_{2} \mathrm{O}-3$ profiles.

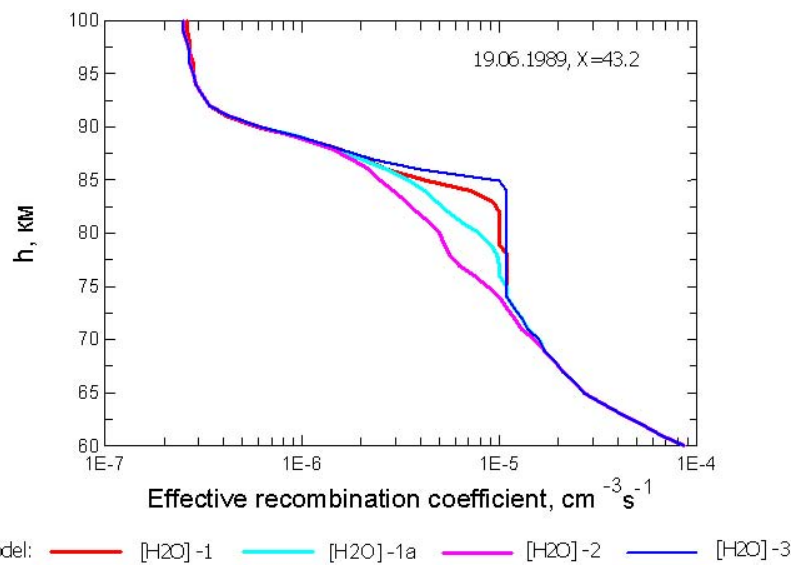

Fig. 7c. Effective recombination coefficient profiles for 19 June 1969 at 15:00 UT, with a solar zenith angle of $43.2^{\circ}$, $F_{10.7}=149$, and calculated for the $\mathrm{H}_{2} \mathrm{O}-1, \mathrm{H}_{2} \mathrm{O}-1 \mathrm{a}, \mathrm{H}_{2} \mathrm{O}-2$ and $\mathrm{H}_{2} \mathrm{O}-3$ profiles presented in Fig. 2.

in Fig. $7 \mathrm{~b}$ and $\mathrm{c}$. The profiles follow similar patterns to 16 June 2004.

\subsection{Case: 12 August 1976}

This case is very interesting for analysing modelled results because it describes simultaneous measurements of electron number density, $\mathrm{O}_{2}^{+}$and $\mathrm{NO}^{+}$molecular ions densities, $\mathrm{NO}^{+} . \mathrm{H}_{2} \mathrm{O}$ water clusters and $\mathrm{H}^{+} .\left(\mathrm{H}_{2} \mathrm{O}\right)_{n=2,3,4}$ proton hydrates during a rocket flight performed over Wallops Island $\left(37.8^{\circ} \mathrm{N}\right)$ at 10:54 LT (Kopp et al., 1978; Kopp and Herrmann, 1984). These experimental data are shown in Figs. 8, 9 and 10 (black curves). The modelling results for a solar 


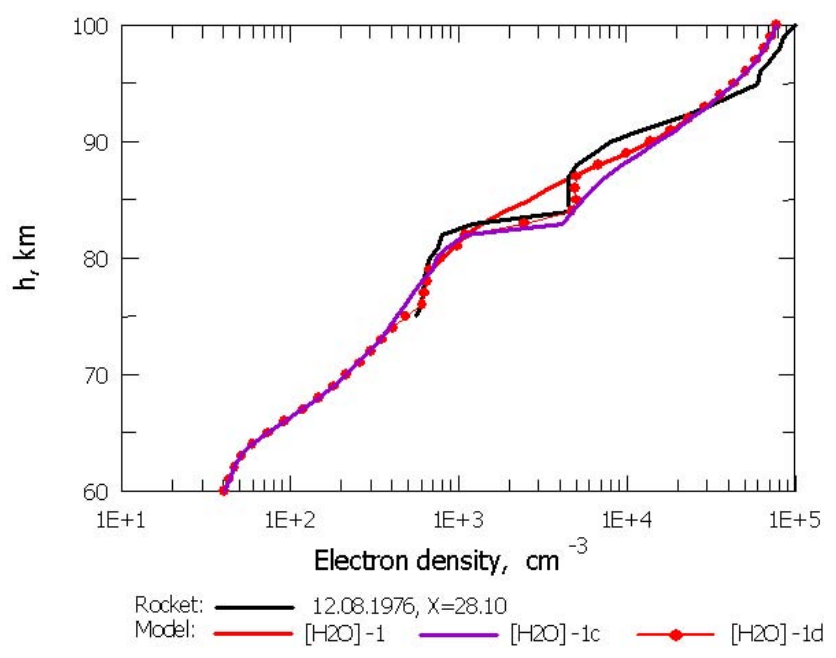

Fig. 8. Electron number density profile measured by Kopp and Herrmann (1984) for 12 August 1976 at 10:54 LT, with a solar zenith angle of $28.10^{\circ}$ (black line) and calculated for the $\mathrm{H}_{2} \mathrm{O}-1, \mathrm{H}_{2} \mathrm{O}-1 \mathrm{c}$ and $\mathrm{H}_{2} \mathrm{O}-1 \mathrm{~d}$ profiles presented in Fig. 11.

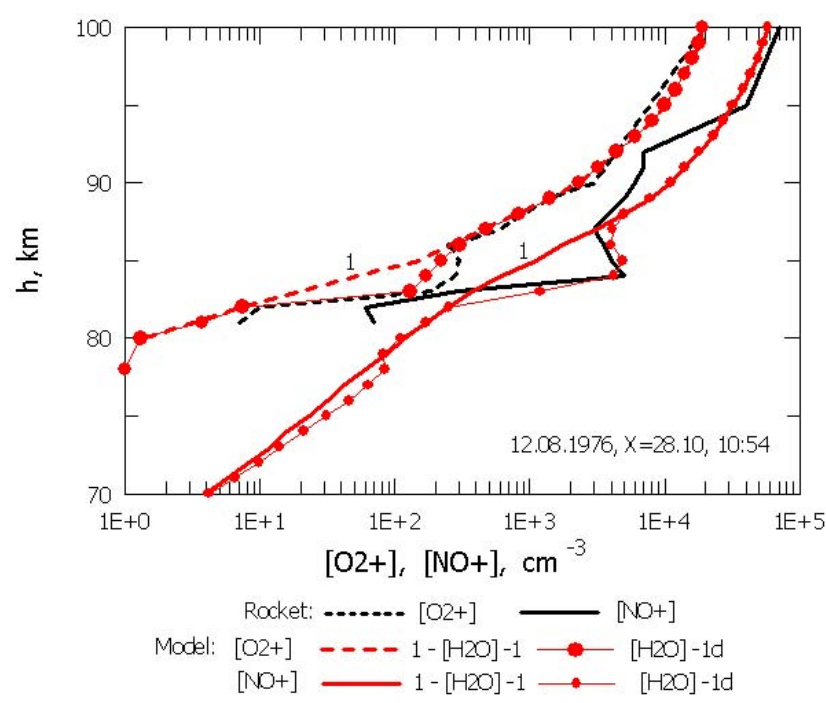

Fig. 9. Number density profiles for the $\mathrm{NO}^{+}$and $\mathrm{O}_{2}^{+}$molecular ions calculated for 12 August 1976 at 10:54 LT, with a solar zenith angle of $28.10^{\circ}$ using the $\mathrm{H}_{2} \mathrm{O}-1$ (red lines without symbols) and $\mathrm{H}_{2} \mathrm{O}-1 \mathrm{~d}$ (red lines with symbols) profiles. The black lines represent $\mathrm{NO}^{+}$(solid) and $\mathrm{O}_{2}^{+}$(dashed) profiles measured by Kopp and Herrmann (1984).

activity index of $F_{10.7}=78$ with the NO- 1 d and $\mathrm{H}_{2} \mathrm{O}-1$ profiles are shown using red curves without symbols. The modelled electron number density and ion composition profiles are not able to reproduce the sharp gradients found in the experimental data. Because the gradients at $82 \mathrm{~km}$ are observed not only for electron number density but also for positive ions, it is likely that these gradients may be caused by peculiarities in the water vapour altitude distribution.

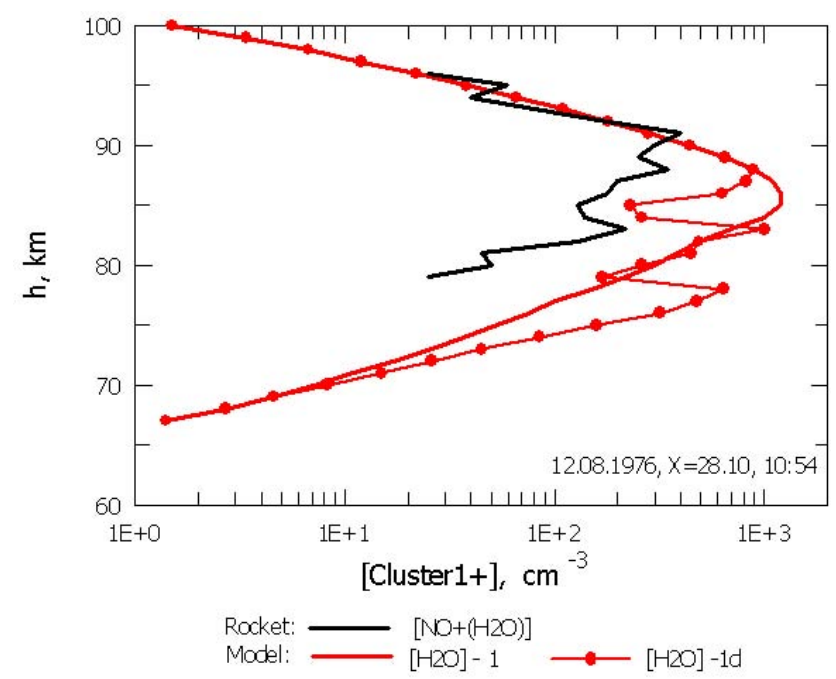

Fig. 10a. Number density profiles of the $\mathrm{Cl}_{1}^{+}$positive cluster family calculated for 12 August 1976 at 10:54 LT, with a solar zenith angle of $28.10^{\circ}$ using the $\mathrm{H}_{2} \mathrm{O}-1$ (red line without symbols) and $\mathrm{H}_{2} \mathrm{O}-1 \mathrm{~d}$ (red line with symbols) profiles. The black line represents the number density profile for the $\mathrm{NO}^{+} . \mathrm{H}_{2} \mathrm{O}$ hydrated cluster ion measured by Kopp et al. (1978).

In this study we have attempted to select water vapour profiles that can reproduce experimental altitude profiles for electrons, $\mathrm{O}_{2}^{+}, \mathrm{NO}^{+}, \mathrm{Cl}_{1}^{+}$and $\mathrm{Cl}_{2}^{+}$, between 75 and $87 \mathrm{~km}$. The $\mathrm{H}_{2} \mathrm{O}-1$ profile was artificially modified into the $\mathrm{H}_{2} \mathrm{O}-1 \mathrm{c}$ and $\mathrm{H}_{2} \mathrm{O}-1 \mathrm{~d}$ profiles presented in Fig. 11. The $\mathrm{H}_{2} \mathrm{O}-1 \mathrm{c}$ profile, with a sharp gradient of a few orders of magnitude above $82 \mathrm{~km}$, reproduces a sharp gradient in the electron number density. However, the $\mathrm{H}_{2} \mathrm{O}-1 \mathrm{c}$ profile is not able to depict the characteristic behaviour of the electron number density between 84 and $87 \mathrm{~km}$. The $\mathrm{H}_{2} \mathrm{O}-1 \mathrm{~d}$ profile reconstructs all characteristic features for electrons (Fig. 8) and provides $\mathrm{O}_{2}^{+}$ and $\mathrm{NO}^{+}$number densities that are close to the experimental data (Fig. 9).

Figure 10a shows the $\mathrm{NO}^{+} \cdot \mathrm{H}_{2} \mathrm{O}$ altitude profile observed by Kopp et al. (1978) (black curve) and $\mathrm{Cl}_{1}^{+}$profiles modelled with the $\mathrm{H}_{2} \mathrm{O}-1$ and $\mathrm{H}_{2} \mathrm{O}-1 \mathrm{~d}$ profiles. The model reproduces the upper boundary of the hydrate cluster layer fairly accurately. Disagreements between the experimental and modelled numerical hydrate cluster densities are likely related to the overestimates in modelled values because the model considers the sum of $\mathrm{NO}^{+}$and $\mathrm{O}_{2}^{+}$water clusters. Figure $10 \mathrm{~b}$ shows that the modelled and measured proton hydrate densities between 80 and $85 \mathrm{~km}$ agree well; the proton hydrate layer upper border for number densities greater than $20 \mathrm{~cm}^{-3}$ nearly coincides.

Figure 12 shows the effect of different water vapour profiles on the effective recombination coefficient. 


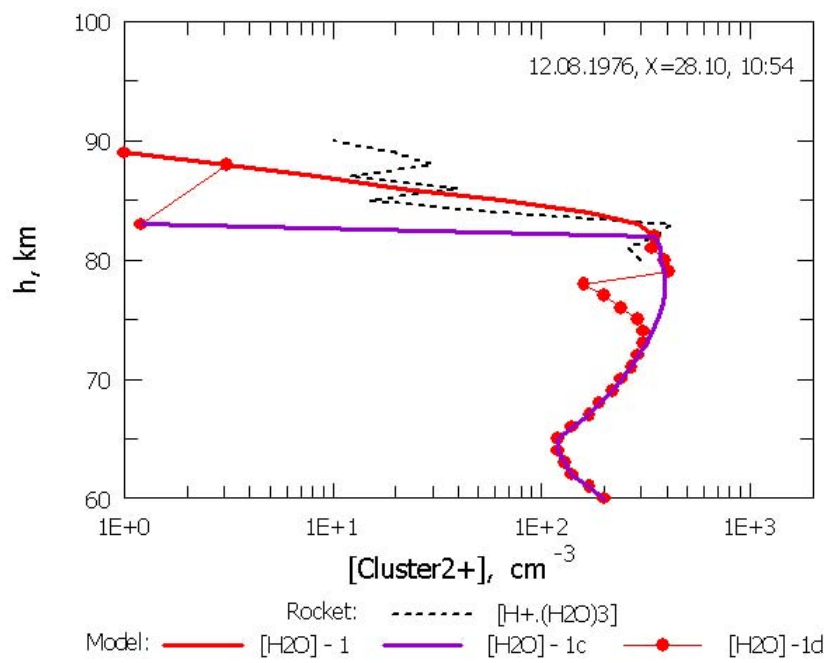

Fig. 10b. Number density profiles of the $\mathrm{Cl}_{2}^{+}$positive cluster family calculated for 12 August 1976 at 10:54 LT, with a solar zenith angle of $28.10^{\circ}$ using the $\mathrm{H}_{2} \mathrm{O}-1$ (red line without symbols) and $\mathrm{H}_{2} \mathrm{O}$ $1 \mathrm{~d}$ (red line with symbols) profiles. The black line represents the number density profile for $\mathrm{H}^{+}\left(\mathrm{H}_{2} \mathrm{O}\right)_{3}$ proton hydrates measured by Kopp et al. (1978).

\section{Summary and conclusions}

Using the PGI ion chemistry model, we have evaluated the efficiencies for channels forming hydrated cluster ions from the $\mathrm{NO}^{+}$and $\mathrm{O}_{2}^{+}$primary ions - i.e. $B\left(\mathrm{NO}^{+}\right)$and $B\left(\mathrm{O}_{2}^{+}\right)$, respectively - and $\mathrm{H}^{+}\left(\mathrm{H}_{2} \mathrm{O}\right)_{n}$ proton hydrates, $B\left(\mathrm{Cl}_{1}^{+}\right)$, at different altitudes in the ionospheric $\mathrm{D}$ region using the different water vapour concentration profiles shown in Fig. 2. Below $60 \mathrm{~km}$, the efficiency of $\mathrm{NO}^{+}$ion direct hydration is always higher than for indirect hydration. Moreover, above $60 \mathrm{~km}$, the efficiency of $\mathrm{NO}^{+}$direct hydration decreases sharply. Therefore, $\mathrm{NO}^{+} \cdot \mathrm{H}_{2} \mathrm{O}$ formation occurs primarily via indirect hydration. Increased water vapour concentration above $60 \mathrm{~km}$, from the $\mathrm{H}_{2} \mathrm{O}-2$ profile to the $\mathrm{H}_{2} \mathrm{O}-1$ profile, increases the efficiency of $\mathrm{NO}^{+}$indirect hydration. The efficiency of $\mathrm{O}_{2}^{+}$ion direct hydration is always less than for indirect hydration. The $\mathrm{B}\left(\mathrm{O}_{2}^{+}\right)$efficiency of the $\mathrm{O}_{2}^{+} \rightarrow \mathrm{O}_{2}^{+} \cdot \mathrm{H}_{2} \mathrm{O}$ channel, i.e. the efficiency of $\mathrm{O}_{2}^{+}$indirect hydration, depends on the water vapour concentration only above $70 \mathrm{~km}$.

Below $70 \mathrm{~km}$, the efficiency of the channel forming proton hydrates, $B\left(\mathrm{Cl}_{1}^{+}\right)$, is higher than $B\left(\mathrm{NO}^{+}\right)$and $B\left(\mathrm{O}_{2}^{+}\right)$ for all water vapour concentrations. Above $70 \mathrm{~km}$, the efficiency of the $\mathrm{Cl}_{1}^{+} \rightarrow \mathrm{Cl}_{2}^{+}$channel is substantially less than $B\left(\mathrm{NO}^{+}\right)$for low water concentrations. However, $B\left(\mathrm{Cl}_{1}^{+}\right)$ approaches $B\left(\mathrm{NO}^{+}\right)$with increased water vapour concentration (Fig. 3b). Changes of effective parameters $B\left(\mathrm{NO}^{+}\right)$ and $B\left(\mathrm{Cl}_{1}^{+}\right)$with a season (Figs. $4 \mathrm{a}, \mathrm{b}$ ) are mainly due to seasonal variations of the neutral mesospheric temperature (the winter temperature is greater than the summer one). Since the effective parameter $B\left(\mathrm{Cl}_{1}^{+}\right)$has a very

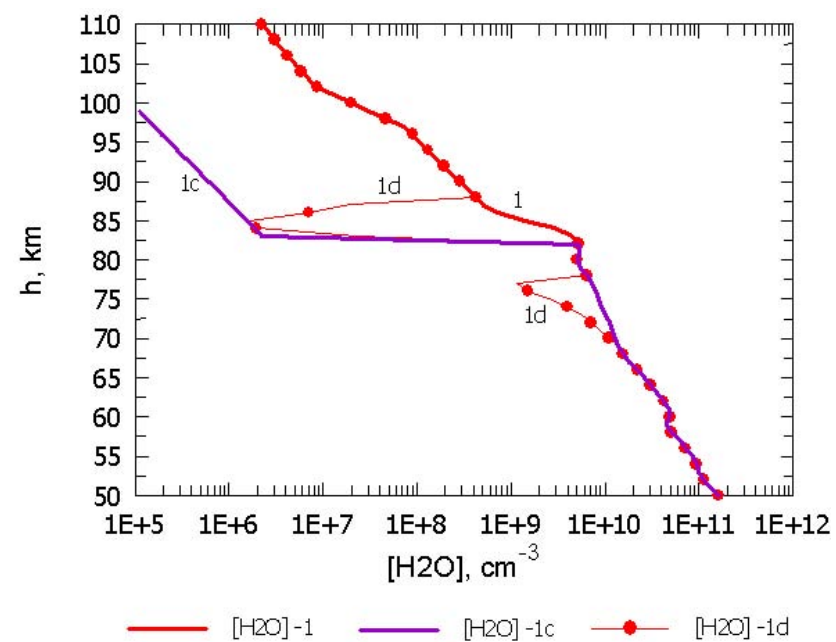

Fig. 11. Water number density profiles. The $\mathrm{H}_{2} \mathrm{O}-1$ profile (red line without symbols) was retrieved from the UARS measurements (http://haloe.gats-inc.com/home/index.php). The $\mathrm{H}_{2} \mathrm{O}-1 \mathrm{c}$ (violet line) and $\mathrm{H}_{2} \mathrm{O}-1 \mathrm{~d}$ (red line with symbols) profiles are modelled for 12 August 1976 at 10:54 LT, based on the measured electron number density shown with a black line in Fig. 8.

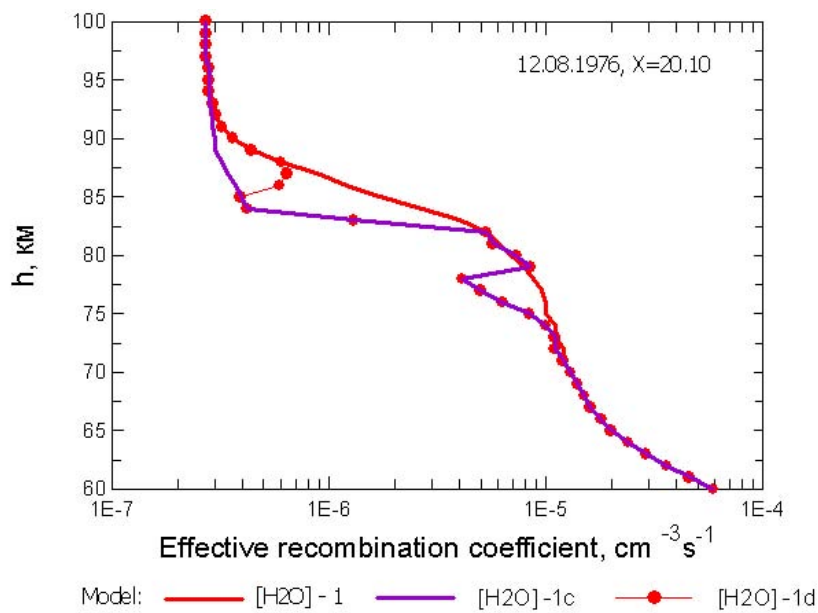

Fig. 12. Effective recombination coefficient calculated for $12 \mathrm{Au}-$ gust 1976 at 10:54 LT, with a solar zenith angle of $28.10^{\circ}$ and the $\mathrm{H}_{2} \mathrm{O}-1$ (red line without symbols), $\mathrm{H}_{2} \mathrm{O}-1 \mathrm{c}$ (violet line) and $\mathrm{H}_{2} \mathrm{O}-$ 1d (red line with symbols) profiles.

strong inverse temperature dependence $\left(B\left(\mathrm{NO}^{+}\right) \propto T^{-13.9}\right)$ but $B\left(\mathrm{Cl}_{1}^{+}\right.$) is proportional to $T^{-4.4}$ (Smirnova and Vlaskov, 1983; Smirnova et al., 1988), variations of the $B\left(\mathrm{NO}^{+}\right)$with season are more pronounced than those of the $B\left(\mathrm{Cl}_{1}^{+}\right)$. The influence of the water vapour concentration on $\mathrm{B}\left(\mathrm{NO}^{+}\right)$is greater in winter than in summer, because of the higher temperature. Water vapour can modify the position of the $\mathrm{Cl}_{1}^{+}$ layer lower bound and the position of $\mathrm{Cl}_{2}^{+}$layer upper border (Figs. 5b, 7b, 10a). If the water vapour concentration 
increases $\left(\mathrm{H}_{2} \mathrm{O}-2 \rightarrow \mathrm{H}_{2} \mathrm{O}-1 \rightarrow \mathrm{H}_{2} \mathrm{O}-3\right)$, the proton hydrate layer expands because its upper border moves upward. Therefore, the vertical interval of the $\mathrm{Cl}_{1}^{+}$layer decreases because the layer's lower border shifts upwards. The location of $\mathrm{Cl}_{1}^{+}$layer upper border does not change. These changes in the vertical distribution of the $\mathrm{Cl}_{1}^{+}$and $\mathrm{Cl}_{2}^{+}$layers cause growth of the proton hydrates $\mathrm{Cl}_{2}^{+}$concentration and strong variations in the effective recombination coefficient between 75 and $87 \mathrm{~km}$ (Fig. 6b, 7c, 12). As a result, variations in the water vapour concentration affect parameter $f^{+}$(Fig. 6a) and the number densities of the primary positive ions (Figs. 5c, 9) and electrons (Figs. 5a, 7a, 8).

Increased water vapour concentration, from the $\mathrm{H}_{2} \mathrm{O}-2$ profile to the $\mathrm{H}_{2} \mathrm{O}-1$ profile, leads to increases in $\alpha_{\mathrm{d}}$ and $\alpha_{\text {eff }}$ (Fig. 6b, 7c) and consequently decreased electron number density between 75 and $87 \mathrm{~km}$ because $\alpha_{\mathrm{d}}$ is primarily determined by the dissociative recombination coefficient for proton hydrates, $\alpha_{\mathrm{Cl}_{2}^{+}}$. Outside this altitude range, the effective recombination coefficient and the electron number density do not respond to large changes in the water vapour concentration that occur at other altitudes in the mesosphere.

Furthermore, the subsequent large increase in the water vapour concentration during the $\mathrm{H}_{2} \mathrm{O}-1 \rightarrow \mathrm{H}_{2} \mathrm{O}-3$ transition modifies the $\mathrm{Cl}_{1}^{+}$and $\mathrm{Cl}_{2}^{+}$number densities only within a very narrow altitude interval, i.e. between 82 and $86 \mathrm{~km}$, and does not lead to substantial variations in either the effective recombination coefficient or electron number density. Therefore, the modelled results show that there are upper limits for water vapour concentration beyond which the $\mathrm{Cl}_{2}^{+}$and $\mathrm{Cl}_{1}^{+}$number densities, effective recombination coefficient and electron number density in the summer ionosphere are not sensitive to the subsequent increases in water vapour. In the applied model the water vapour concentration upper limits are described by a profile that is closer to the $\mathrm{H}_{2} \mathrm{O}-1$ profile measured in the summer mesosphere by the UARS (http: //haloe.gats-inc.com/home/index.php). Moreover, the electron density profiles modelled based on the $\mathrm{H}_{2} \mathrm{O}-1$ profile correlate well with the electron density measurements from 16 June 2004 and 19 June 1989.

For the event with the observed sharp gradients in positive ion and electron number densities, we modelled a profile with an inhomogeneous water vapour distribution (the $\mathrm{H}_{2} \mathrm{O}$ 1d profile in Fig. 11) that can reproduce the characteristic behaviour of ionospheric parameters. A sharp decrease in the water vapour above $82 \mathrm{~km}$, shown by the $\mathrm{H}_{2} \mathrm{O}-1 \mathrm{c}$ profile in Fig. 11, results in the disappearance of the proton hydrate layer (Fig. 10b), contradicting the observations of Kopp et al. (1978). Here, the effective recombination coefficient between 82 and $88 \mathrm{~km}$ approaches the average dissociative recombination coefficient, $\alpha_{\mathrm{d}}$, for the $\mathrm{NO}^{+}$and $\mathrm{O}_{2}^{+}$molecular ions, and the modelled electron density strongly exceeds the experimental values.

Under quiet geophysical conditions the theoretical model of the ionisation-recombination cycle in the $\mathrm{D}$ region can be applied for studies of water vapour altitude distribution in the mesosphere. For the case study on 12 August 1976 it was shown that water vapour altitude profiles obtained on the basis of the experimental electron density profiles can be inhomogeneous. Such water profiles might explain sharp gradients in number densities of positive ions and electrons observed during the rocket experiments.

Acknowledgements. The authors thank the Education, Audiovisual and Culture Executive Agency (EACEA) for support of this work within the frame of the Erasmus Mundus Master Course in Space Science and Technology - SpaceMaster, 2009-2013.

Topical Editor K. Hosokawa thanks two anonymous referees for their help in evaluating this paper.

\section{References}

Arnold, F.: The middle ionized component, Proc. ESA Symposium on rocket and balloon programmers, Boumemouth, 1980.

Arnold, F. and Krankowsky, D. F.: Negative ions in the lower ionosphere. A comparison of a model computation and massspectrometer measurements, J. Atmos. Terr. Phys., 33, 1693 $1702,1971$.

Albritton, D. L.: Ion-neutral reaction-rate constants measured in flow reactions through 1977, Atom. Data Nucl., 22, 1-101, 1978.

Barabash, V., Osepian, A., Dalin, P., and Kirkwood, S.: Electron density profiles in the quiet lower ionosphere based on the results of modeling and experimental data, Ann. Geophys., 30, 13451360, doi:10.5194/angeo-30-1345-2012, 2012.

Brasseur, G. and Salomon, S.: Aeronomy of the Middle Atmosphere, 2nd Edn., D. Reidel Publishing Company, Dorhrecht, Holland, 1986.

Brekke, A., Holt, O., Dickinson, P. H. G., Friedrich, M., Hansen, T., Stauning, P., and Thrane, E. V.: Development of D region electron and ion densities under various auroral conditions during the Energy Budget Campaign (EBC), J. Atmos. Terr. Phys., 47, 101-121, 1985.

Chakrabarty, D. K., Chakrabarty, P., and Witt, G.: An attempt to identify the obscured paths of water positive ions build-up in the D region, J. Atmos. Terr. Phys., 40, 437-442, 1978.

Cosby, P. C., Moseley, J. T., and Peterson, J. R.: Photodissociation spectroscopy of $\mathrm{O}_{3}^{-}$, J. Chem. Phys., 70, 2771-2778, 1978.

Danilov, A. D. and Simonov, A. G.: A simplified model of the D region, Geomagn, Aeronomy, 1981.

Danilov, A. D. and Smirnova, N. V.: Ion composition and photochemistry of the lower thermosphere. 2. Ion composition of the D- and E-regions, Geomagn. Aeron., 33, 120-133, 1993.

Danilov, A. D. and Smirnova, N. V.: Improving the 75 to $300 \mathrm{~km}$ ion composition model of the IRI, Adv. Space Res., 15, 171-178, doi:10.1016/S0273-1177(99)80044-1, 1994.

Danilov, A. D. and Smirnova, N. V.: Comparison of the mid-latitude model with low-latitude ion composition data, Adv. Space Res. 31, 687-696, 2003.

Danilov, A. D. and Yaichnikov, A. P.: A new model of the ion composition at 75 to $1000 \mathrm{~km}$ for IRI, Adv. Space Res., 5, 75-79, 1985. 
Derblom, H. and Laddel, L.: D region parameters at high latitudes obtained from rocket experiments, J. Atmos. Terr. Phys., 35, 12, 2123-2130, 1973.

Dunkin, D. B., Fehsenfeld, F. C., Schmelrekopf, A. L., and Ferguson, E. E.: Three-body association reactions of $\mathrm{NO}^{+}$with $\mathrm{O}_{2}$, $\mathrm{N}_{2}$ and $\mathrm{CO}_{2}$, J. Chem. Phys., 54, 3817-3822, 1971.

Fehsenfeld, F. C. and Fergusson, E. E.: Origin of water cluster ions in the D region, J. Geophys. Res., 74, 2217-2222, 1969.

Fehsenfeld, F. C. and Fergusson, E.: Laboratory studies of negative ion reactions with atmosphere trace constituents. Origin of water cluster ions in the D region, J. Chem., Phys., 61, 3181-3193, 1974.

Ferguson, E. E.: D region ion chemistry, Rev. Geophys. Space Phys., 9, 997-1008, 1971a.

Ferguson, E. E.: Laboratory measurements of D region ionmolecule reactions, in Mesospheric Models and Related Experiments, edited by: Flocco, G., Reidel Dordrecht, 188-197, 1971 b.

Ferguson, E. E.: Laboratory measurements of ionospheric ionmolecule reaction rates, Rev. Geophys. Space Phys., 12, 703713, 1974.

Ferguson, E. E.: D region ion chemistry, Rev. Geophys. Space Phys., 9, 997-1008, 1976.

Fritzenwallner, J. and Kopp, E.: Model calculations of the negative ion chemistry in the mesosphere with special emphasis on the chlorine species and the formation of cluster ions, Adv. Space Res., 21, 891-894, 1998.

Funke, B., Baumgaertner, A., Calisto, M., Egorova, T., Jackman, C. H., Kieser, J., Krivolutsky, A., López-Puertas, M., Marsh, D. R., Reddmann, T., Rozanov, E., Salmi, S.-M., Sinnhuber, M., Stiller, G. P., Verronen, P. T., Versick, S., von Clarmann, T., Vyushkova, T. Y., Wieters, N., and Wissing, J. M.: Composition changes after the "Halloween" solar proton event: the High Energy Particle Precipitation in the Atmosphere (HEPPA) model versus MIPAS data intercomparison study, Atmos. Chem. Phys., 11, 90899139, doi:10.5194/acp-11-9089-2011, 2011.

Gabriel, A., Körnich, H., Lossow, S., Peter, D. H., Urban, J., and Murtagh, D.: Zonal asymmetries in middle atmospheric ozone and water vapour derived from Odin satellite data 2001-2010, Atmos. Chem. Phys., 11, 9865-9885, 2011,

http://www.atmos-chem-phys.net/11/9865/2011/.

Grygalashvyly, M., Sonnemann, G. R., and Hartogh, P.: Long-term behavior of the concentration of the minor constituents in the mesosphere - a model study, Atmos. Chem. Phys., 9, 2779-2792, doi:10.5194/acp-9-2779-2009, 2009.

Gumbel, J. and Witt, G.: Cluster ions and ice particle nucleation: Positive feedback at the summer mesopause, J. Geophys. Res. Lett., 29, 29.1-29.4, doi:10.1029/2002GL015146, 2002.

Hartogh, P., Sonnermann, G. R., Grygalashvily, M., Li Song, Berger, U., and Lübken, F. J.: Water vapour measurements at ALOMAR over a solar cycle compared with model calculations by LIMA, J. Geophys. Res, 115, D00117, doi:10.1029/2009JD012364, 2010.

Haug, A. and Landmark, B.: A two-ions model of electron-ion recombination in the D region, J. Atmos. Terr. Phys., 32, 405-407, doi:10.1016/0021-9169(70)90012-7, 1970.

Hedin, A. E.: Extension of the MSIS thermospheric model into the middle and lower atmosphere, J. Geophys. Res. 96, 1159-1172, 1991.
Hervig, M. and Siskind, D.: Decadal and inter-hemispheric variability in polar mesospheric clouds, water vapour, and temperature, J. Atmos. Terr. Phys., 68, 30-41, 2006.

Hodges, R. V., Lee, L. C., and Moseley, J. T.: Photodissociation and photodetachment of molecular negative ions, J. Chem. Phys., 72, 2998-3000, 1980.

Jackman, C. H. and Meade, P. E.: Effect of solar proton events in 1978 and 1979 on the odd nitrogen abundance in the middle atmosphere, J. Geophys. Res., 93, 7984-7090, 1988.

Jackman, C. H., Cerniglia, M. C., Nielsen, J. E., Allen, D. J., Zawodny, J. M., McPeters, R. D., Douglass, A. R., Rosenfield, J. E., and Rood, R. B.: 2D and 3D model simulations, measurements, and interpretation of the influence of the October 1989 solar proton events in the middle atmosphere, J. Geophys., Res., 100, 11641-11660, 1995.

Jackman, C. H., McPeters, R. D., Lanow, G. J., Fleming, E. L., Praderas, C. J., and Russel, M.: Northern hemisphere atmospheric effects due to the July 2000 solar proton event, Geophys. Res. Lett., 28, 2883-2886, 2001.

Jackman, C. H., DeLand, M. T., Labow, G. J., Fleming, E. L., Weisentein, D. K., Ko, M. K. W., Sinnhuber, M., Anderson, J., and Russell, J. M.: The influence of the several very large solar proton events in years 2000-2003 on the neutral middle atmosphere, J. Adv. Space Res., 35, 445-450, 2005.

Johannessen, A. and Krankowsky, D.: Positive-ion composition measurement in the upper mesosphere and lower thermosphere at high latitudes during summer, J. Geophys. Res., 77, 2888-2901, 1972.

Kazil, J., Kopp, E., Chabrillat, S., and Bishop, J.: The University of Bern Atmospheric Ion Model: Time dependent modelling of the ions in the mesosphere and lower thermosphere, J. Geophys. Res., 18, 4432, doi:10.1029/2002JD003024, 2003.

Kirkwood, S., Osepian, A., and Smirnova, N.: Quantitative description of electron precipitation during auroral absorption events in the morning and around noon local time sectors, J. Atmos. Sol.Terr. Phys., 63, 1907-1921, 2001.

Kopp, E. and Herrmann, U.: Ion composition in the lower ionosphere, Ann. Geophys., 2, 84-94, 1984,

http://www.ann-geophys.net/2/84/1984/.

Kopp, E., Eberhardt, P., and Hermann, U.: Summer daytime positive ion composition in the $\mathrm{D}$ region above Wallop Island, in COSPAR: Space Research, Vol. XVIII, edited by: Mycroft, M. J. and Stickland, A. C., 245-248, Pergamon, New York, 1978.

Kopp, E., Eberhardt, P., Hermann, U., and Björn, L. G.: Positive ion composition of the high latitude summer $\mathrm{D}$ region with noctilucent clouds, J. Geophys. Res., 90, 148-227, 1985.

Krankowsky, D., Lämmerzahl, P., Götzelmann, A.: Positive ion composition in the lower ionosphere at high latitudes during MAP/WINE, J. Atmos. Terr. Phys., 49, 809-818, 1987.

Kull, A., Kopp, E., Granier, C., and Brasseur, G.: Ions and electrons of the lower-latitude D region, J. Geophys. Res.,102, 9705-9716, 1997.

Lopez-Puertas, M., Funke, B., Gil-Lopez, S., von Clarmann, T., Stiller, G. P., Höpfner, M., Kellmann, S., Mengistu Tsidu, G., Fischer, H., and Jackman, C. H.: $\mathrm{HNO}_{3}, \mathrm{~N}_{2} \mathrm{O}_{5}$ and $\mathrm{ClONO}_{2}$ enhancements after the October-November 2003 solar proton event, J. Geophys. Res., 110, AOS44, doi:10.1029/2005JA011051, 2005. 
Lossow, S., Joachim, U., Eriksson, P., Murtagh, D., and Gumbel, D.: Critical parameters for the retrieval of mesospheric water vapour and temperature from Odin/SMR limb measurements at $557 \mathrm{GHz}$; Advances in Space Research, COSPAR, Elsevier Ltd, doi:10.1016/j.asr.2007.05.026, 2007.

Mitra, A. P. and Rowe, J. N.: Ionospheric effects of solar flares-IV, changes in D region ion chemistry during solar flares, J. Atmos., Terr. Phys., 34, 795-806, 1972.

Nacisi, R. S., Bailej, A. D., Della Lucca, L., Sherman, C., and Thomas, D. M.: Mass spectrometric measurements of negative ions in the D-e and lower E regions, J. Atmos. Terr. Phys., 33, 1147-1159, 1971.

Ogawa, T. and Shimazaki, T.: Diurnal variations of odd nitrogen and ionic densities in the mesosphere and lower thermosphere: simultaneous solution of photochemical-diffusive equations, J. Geophys. Res., 80, 3945-3960, 1975.

Osepian, A., Tereschenko, V., Dalin, P., and Kirkwood, S.: The role of atomic oxygen concentration in the ionization balance of the lower ionosphere during solar proton events, Ann. Geophys., 26, 131-143, doi:10.5194/angeo-26-131-2008, 2008.

Osepian, A., Kirkwood, S., and Dalin, P.: Influence of ozone concentration on the lower ionosphere- modelling and measurements during the 29-30 October 2003 solar proton event, Ann. Geophys., 27, 577-589, 2009a,

http://www.ann-geophys.net/27/577/2009/.

Osepian, A., Kirkwood, S., Dalin, P., and Tereschenko, V.: D-region electron density and effective recombination coefficients during twilight - experimental data and modelling during solar proton events, Ann. Geophys., 27, 3713-3724, doi:10.5194/angeo-273713-2009, 2009b.

Picone, J. M., Hedin, A. E., Drob, D. P., and Aikin, A. C.: NRLMSISE-00 empirical model of the atmosphere: Statistical comparisons and scientific issues, J. Geophys. Res., 107, 1468, doi:10.1029/2002JA009430, 2002.

Reid, G. C.: The production of water cluster positive ions in the quiet daytime D region, Planet. Space Sci., 25, 3, 275-290, 1977.

Reid, G. C.: Radar observations of negative-ion photodetachment at sunrise in the auroral- zone mesosphere, Planet. Space Sci., 35, 27-37, 1987.

Rishbeth, H. and Garriott, K.: Introduction to Ionospheric Physics, Academic Press, New York, 1969.

Rodrigo, R., Lopez-Moreno, J. J., Lopez-Puertas, M., Moreno, F., and Molina, A.: Neutral atmospheric composition between 60 and $220 \mathrm{~km}$ : A theoretical model for mid-latitudes, Planet. Space Sci., 34, 723-743, 1986.

Rohen, G., von Savigny, C., Sinnhuber, M., Liewellyn, E. J., Kauser, J. W., Jackman, C. H., Kallenrode, M. B., Schröter, J., Eichmann, K.-U., Bovensmann, H., and Burrows, J. P.: Ozone depletion during the solar proton events of October/November 2003 as seen by SCIAMACHY, J. Geophys. Res., 110, A09S39, doi:10.1029/2004JAO10984, 2005.

Seppala, A., Verronen, P. T., Kyrölä, E., Hassinen, S., Backman, L., Hauchecorne, A., Bertaux, J. L., and Fussen, D.: Solar proton events of Ocotber-November 2003: ozone depletion in the northern hemisphere polar winter as seen by GOMOS/Envisat, J. Geophys. Res. Lett., 31, L19107, doi:10.1029/2004GL021042, 2004.

Seppala, A., Verronen, P. T., Cilverd, M. A., Randall, C. E., Tamminen, J., Sofieva, V., Beckman, L., and Kyrölä, E.: Arc- tic and Antarctic polar winter $\mathrm{NO}_{\mathrm{x}}$ and energetic particle precipitation in 2002-2006, J. Geopys. Res. Lett., 34, L12810, doi:10.1029/2007GL029733, 2007.

Shimazaki, T.: The photochemical time constants of minor constituents and their families in the middle atmosphere, J. Atmos. Terr. Phys., 46, 173-191, 1984.

Shimazaki, T. and Laird, A.: A model calculation of the diurnal variation in minor neutral constituents in the mesosphere and lower thermosphere including transport effects, J. Geophys. Res., 75, 3221-3235, 1970.

Smirnova, N. V.: Modeling of the ionization-recombination cycle in the $\mathrm{D}$ region., Mathematical modelling of the complex processes, Academy of Sciences of the USSR, 22-34, 1982 (in Russian).

Smirnova, N. V.: The D region during SP-events: the formation rates of the positive cluster ions and negative ions. Ionospheric Research, Academy of Sciences of the USSR, 35, 67-75, 1983a (in Russian).

Smirnova, N. V.: The model of the ionization-recombination cycle in the $\mathrm{D}$ region, $\mathrm{PhD}$ thesis, VINITI, Academy of Sciences of the USSR, 1983b (in Russian).

Smirnova, N. V. and Vlaskov, V. A.: The negative ions in the ionospheric D region, Preprint PGI-82-3-17, Apatity, 46, 1982a (in Russian).

Smirnova, N. V. and Vlaskov V. A.: Seasonal variations of the ion composition. Mathematical modelling of the complex processes, Academy of Sciences of the USSR, 83-96, 1982b (in Russian).

Smirnova, N. V. and Vlaskov, V. A.: Aeronomic aspects of the D region winter anomaly, Preprint PGI-8, Apatity, 20, 1983 (in Russian).

Smirnova, N. V., Ogloblina, O. F., and Vlaskov, V. A.: Modeling of the lower ionosphere, Pageoph., 127, 353-379, 1988.

Smith, D. and Church, M. J.: Ion-ion reaction rates in the earth's atmosphere, Planet. Space Sci., 25, 433-439, 1977.

Smith, D., Adams N. G., and Church M. J.: Mutual neutralization rates of ionospherically important ions, Planet. Space Sci., 24, 697-703, 1976.

Smith, G. P., Lee, L. C., and Moseley, J. T.: Photodissociation and photodetachement of molecular negative ions. VII. Ions formed in $\mathrm{CO}_{2} / \mathrm{O}_{2} / \mathrm{H}_{2} \mathrm{O} /$ mixtures 3500-5300 $\AA$, J. Chem. Phys., 71, 4024-4031, 1979.

Singer, W., Latteck, R., Friedrich, M., Wakabayashi, M., and Rapp, M.: Seasonal and solar activity variability of $\mathrm{D}$ region electron density at $69^{\circ}$ N, J. Atmos. Terr. Phys., 73, 925-935, 2011.

Solomon, S., Rusch, D. W., Gerard, J. C., Reid, G. C., and Crutsen, P. J.: The effect of particle precipitation events on the neutral and ion chemistry of the middle atmosphere: II. Odd hydrogen, J. Planet. Space Sci., 29, 885-893, 1981.

Solomon, S., Reid, G. C., Roble, R. G., and Crutsen, P. J.: Phothochemical coupling between the thermosphere and lower atmosphere, 2. D region ion chemistry and the winter anomaly, J. Geophys. Res., 87, 7221-7227, 1982.

Sonnemann, G. R., Grygalashvily, M., and Berger, U.: Autocatalytic water vapour production as asource of large mixing ratios within the middle to upper mesosphere, J. Geohys. Res., 110, D15303, doi:10.1029/2004JD005593, 2005.

Sonnemann, G. R., Hartogh, P., Grygalashvily, M., Berger, U., Lübken, F. J., and Grygalashvily, M.: Antropogenic effects on the distribution of minor chemical constituents in the meso- 
sphere/lowe thermosphere - a model study, Adv. Space Res., COSPAR, Elsevier Ltd., doi:10.1016/j.asr.2012.05.016, 2012.

Summers, M. E., Conway, R. R., Englert, C. R., Siskind, D. E., Stevens, M. H., Russel, J. M., Gordley, L. L., and McHugh, M. J.: Discovery of a water vapour layer in the Arctic summer mesosphere: implications for polar mesospheric clouds, Geophys. Res. Lett., 28, 3601-3604, 2001.

Thomas, L.: NO ${ }^{+}$and water cluster ions in the D region, J. Atmos. Terr. Phys., 38, 61-67, 1976a.

Thomas, L.: Mesospheric temperatures and the formation of water cluster ions in the D region, J. Atmos. Terr. Phys., 38, 12351250, $1976 \mathrm{~b}$.

Thomas, L. and Bowman, M. R.: A study of pre-sunrise changes in negative ions and electrons in the D-region, Ann. Geophys., 4, 219-228, 1986, http://www.ann-geophys.net/4/219/1986/.

Turco, R. P. and Sechrist, C. F.: An investigation of the ionospheric $\mathrm{D}$ region at sunrise. 2. Estimation of some photodetachment rates, Radio Sci., 7, 717-724, 1972a.

Turco, R. P. and Sechrist, C. F.: An investigation of the ionospheric $\mathrm{D}$ region at sunrise. 1. Time variations of ozone, metastable molecular oxygen and atomic oxygen, Radio Sci., 7, 703-716, 1972b.

Turunen, E., Matveinen, H., and Ranta, H.: Sodankyla Ion Chemistry (SCI) Model, Sodankyla Geophysical Observatory Report, No. 49, Finland, 1992.

Verronen, P. T. and Lehmann, R.: Analysis and parameterisation of ionic reactions affecting middle atmospheric $\mathrm{HO}_{\mathrm{x}}$ and $\mathrm{NO}_{\mathrm{y}}$ during solar proton events, Ann. Geophys., 31, 909-956, doi:10.5194/angeo-31-909-2013, 2013.

Verronen, P. T., Turunen, E., Ulich, Th., and Kyrölä, E.: Modelling the effects of the October 1989 solar proton event on mesospheric odd nitrogen using a detailed ion and neutral chemistry model, Ann. Geophys., 20, 1967-1976, doi:10.5194/angeo-201967-2002, 2002.
Verronen, P. T., Seppälä, A., Clilverd, M. A., Rodger, C. J., Kyrölä, E., Enell, C.-F., Ulich, T., and Turunen, E.: Diurnal variation of ozone depletion during the October-November 2003 solar proton events, J. Geophys. Res., 110, A09S32, doi:10.1029/2004JA010932, 2005.

Verronen, P. T., Seppälä, A., Kyröla, E., Tamminen, J., Pickett, H. M., and Turunen, E.: Production of odd hydrohen in the mesosphere during the January 2005 soplar proton event, Geopyys. Res. Lett., 33, L24811, doi:10.1029/2006GL028115, 2006.

Verronen, P. T., Funke, B., Lopez-Puertas, M., Stiller, G. B., von Clarmann, T., Glatthor, N., Enell, C.-F., Turunen, E., and Tamminene, J.: About the increase of $\mathrm{HNO}_{3}$ in the stratopause region during the Halloween 2003 solar proton event, Geophys. Res. Lett., 35, L20809, doi:10.1029/2008GL035312, 2008.

Verronen, P. T., Santee, M. L., Manney, G. L., Lehmann, R., Salmi, S. M., and Seppälä, A.: Nitric acid enhancements in the mesosphere during the January 2005 and December 2006 solar proton events, J. Geophys. Res., 116, D17301, doi:10.1029/2011JD016075, 2011.

Vlaskov, V. A., Osepian, A. P., Churikova, T. V., and Turunen, E.: Electron number densities in the auroral zone. Experiment and model, Geomagnetizm i Aeronomiia, 30, 143-146, 1990 (in Russian).

Winkler, H., Kazeminejad, S., Sinnhuber, M., Kallenrode, M.B., and Notholt, J.: Conversion of mesospheric $\mathrm{HCl}$ into active chlorine during the solarproton event in July 2000 in the northern polar region, J. Geophys. Res., 114, D00I03, doi:10.1029/2008JD011587, 2009.

Wisemberg, J. and Kockarts, G.: Negative ion chemistry in the terrestrial D region and signal flow graph theory, J. Geophys. Res., 85, 4642-4652, 1980.

Zadorozhny, A. M.: Diffusion-photochemical model of minor neutral constituents in the lower ionosphere, Academy of Science of USSR, Novosibirsk, 1982 (in Russian). 